\title{
Leghágots'enete (learning together): the importance of indigenous perspectives in the identification of biological variation
}

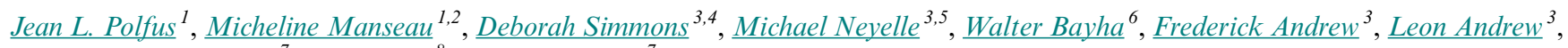 \\ Cornelya F. C. Klütsch ${ }^{7}, \underline{\text { Keren Rice }}^{8}$ and $\underline{\text { Paul Wilson }}^{7}$
}

\begin{abstract}
Using multiple knowledge sources to interpret patterns of biodiversity can generate the comprehensive species characterizations that are required for effective conservation strategies. Caribou (Rangifer tarandus) display substantial intraspecific variation across their distribution and in the Sahtú Region of the Northwest Territories, Canada, three caribou types, each with a different conservation status, co-occur. Caribou are essential to the economies, culture, and livelihoods of northern indigenous peoples. Indigenous communities across the north are insisting that caribou research be community-driven and collaborative. In response to questions that arose through dialogue with five Sahtú Dene and Métis communities, we jointly developed a research approach to understand caribou differentiation and population structure. Our goal was to examine caribou variation through analysis of population genetics and an exploration of the relationships Dene and Métis people establish with animals within bioculturally diverse systems. To cultivate a research environment that supported łeghágots'enetę "learning together” we collaborated with ?ehdzo Got'lnę (Renewable Resources Councils), elders, and an advisory group. Dene knowledge and categorization systems include a comprehensive understanding of the origin, behaviors, dynamic interactions, and spatial structure of caribou. Dene people classify todz1 "boreal woodland caribou" based on unique behaviors, habitat preferences, and morphology that differ from rekwęe "barren-ground" or shúhta repé "mountain" caribou. Similarly, genetic analysis of material (microsatellites and mitochondrial DNA) from caribou fecal pellets, collected in collaboration with community members during the winter, provided additional evidence for population differentiation that corresponded to the caribou types recognized by Dene people and produced insights into the evolutionary histories that contribute to the various forms. We developed culturally respectful and relevant descriptions of caribou variation through partnerships that respect the lives and experiences of people that depend on the land. By prioritizing mutual learning, researchers can broaden their understanding of biodiversity and establish a common language for collaboration.
\end{abstract}

Key Words: aboriginal; biocultural diversity; biodiversity; caribou; collaborative research; ecology; First Nation; genetic variation; indigenous communities; population genetics; population structure; Rangifer tarandus; resource management; social-ecological systems; traditional knowledge

\section{INTRODUCTION}

Patterns of biological variation are a result of the replication of DNA, the potential for DNA mutations and environmental structure that prevents the complete overlap of groups of organisms (Hey 2001). Significant scientific effort has been allocated toward determining where, within the space of genetic and environmental variation, units emerge that merit identification (Padial et al. 2010). Although the articulation of biological categories is a universal human predisposition (Berlin 1973, Atran 1990), the content of named categories reflects a dynamic exchange between morphological, utilitarian, ecological, and perceptual factors, all of which are adapted by different cultures to a particular time and place (Nazarea 2006, Newmaster et al. 2006). The species concept, which has undergone numerous iterations and has been, and continues to be, actively debated by systematists, taxonomists, biologists, and naturalists, illustrates the complexity of assigning objects to categories (Hey 2001). Recently, researchers have begun to acknowledge that many, if not most, species do not have distinct, easy-to-recognize boundaries (Hey 2006, Mallet 2008) and that species may be best described as "poorly differentiated way-stations in a continuous hierarchy of biodiversity" (Mallet 2005:229). However, in order to identify groups that justify protection, such as species or subspecies, scientists and managers require not only a firm understanding of recombination, genetic drift, selection, and gene flow, but also a critical examination of human perception and how people connect with and define their world.

Biodiversity can be categorized in many ways as a result of the inherent complexity and interconnected evolutionary history of life, e.g., introgressive hybridization, horizontal gene transfer, lateral exchange, reticulate evolution, etc. (Mallet 2005, Arnold and Fogarty 2009). Current species taxonomies reflect only one possible grouping structure out of many alternatives (Atran 1990, Lakoff 1990, Newmaster et al. 2006, Padial et al. 2010). Critics of the hierarchical nature of science-based classification systems cite a lack of flexibility necessary to respond to a world that includes ambiguous boundaries (Hey 2006). The subjectivity inherent in species categories can appear inconsequential when two species or populations are clearly distinct, but in situations involving closely related taxa, intraspecific variation, or geographic overlap, it becomes problematic (Mace 2004). The influence of hybridization and introgression among subspecies, populations, and species can be difficult because the conservation

\footnotetext{
${ }^{1}$ Natural Resources Institute, University of Manitoba, Winnipeg, Manitoba, Canada, ${ }^{2}$ Office of the Chief Ecosystem Scientist, Parks Canada, Gatineau, Québec, Canada, ${ }^{3}$ Rehdzo Got'lnę Gots'ę Nákedı (Sahtú Renewable Resources Board), Tulit'a, Northwest Territories, Canada, ${ }^{4}$ Aboriginal Studies, University of Toronto, Toronto, Ontario, Canada, ${ }^{5}$ Délı̨nę Rehdzo Got'lęę (Renewable Resource Council), Délı̨nę, Northwest Territories, Canada, ${ }^{6}$ Délınę Land Corporation, Délınę, Northwest Territories, Canada, ${ }^{7}$ Biology Department, Trent University, Peterborough, Ontario, Canada, ${ }^{8}$ Department of Linguistics, University of Toronto, Toronto, Ontario, Canada
} 
of hybrids, which often display a continuum of genotypes, does not fit a discontinuous species-based conservation model (Fitzpatrick et al. 2015). Further, hybridization often necessitates a subjective decision about the "authenticity" of a certain genotype over another and poses a challenge to endangered species policies, e.g., the hybridization of introduced Mallards (Anas platyrhynchos) with several species of threatened ducks in New Zealand to the point where all previously considered endemic ducks may be of hybrid origin (Rhymer and Simberloff 1996, Fitzpatrick et al. 2015).

The species Rangifer tarandus, known as caribou in North America and reindeer in Scandinavia and Russia, are highly vagile and occur across an extremely diverse spectrum of habitats where they have adapted many different behavioral responses to a range of ecological conditions. Substantial variation in caribou behavior, morphology, life history traits, interactions with other species, movement, diet, and social structures have made attempts to systematically organize and characterize the species challenging. In 1961, Banfield classified R. tarandus in North America into four divisions based on morphological comparisons: barren-ground caribou ( $R$. t. groenlandicus and $R$. t. granti); woodland (R. t. caribou); Peary caribou (R. t. pearyi); and the extinct Dawson's caribou that once occurred on the Haida Gwaii islands of British Columbia (R. t. dawsoni). A range of subjective subdivisions within Banfield's designations have since been applied based on numerous criteria, e.g., calving strategies, ecotype designations, seasonal distributions, etc., resulting in a complicated milieu of inconsistently applied naming conventions that diverge across jurisdictional boundaries. The recent attempt by the Committee on the Status of Endangered Wildlife in Canada to define conservation units for caribou, specifically designatable units (DUs, discrete and significant biological units that capture irreplaceable components of intraspecific biodiversity), found that consistent methods and criteria for organizing the variation inherent to the species are not currently available (COSEWIC 2011). Effective categories are needed because units that ignore underlying ecological relationships or misinterpret population structure lead to confusion when implementing recovery plans and conservation policies (Crandall 2009).

For example, in the Sahtú region of the Northwest Territories, Canada, there is considerable overlap among different caribou herds, groups, and types that exhibit unique life histories and have acquired different conservation statuses (Fig. 1). In the northern portion of the region, large herds of barren-ground caribou migrate between the open tundra and the boreal forest in response to seasonal pulses of resources and predation pressure (Vors and Boyce 2009, Nagy et al. 2011). In the Mackenzie Mountains, caribou display much smaller scale seasonal migrations between valley bottoms and alpine plateaus (Gullickson and Manseau 2000, Polfus et al. 2011, Letts et al. 2012). Throughout the boreal forest, boreal woodland caribou exhibit sedentary behavior and occur in small groups of $\sim 5-15$ individuals (Stuart-Smith et al. 1997, O'Brien et al. 2006, Brown et al. 2007, Courtois et al. 2007). Data on the boundaries and degree of differentiation between these caribou types is currently limited. Understanding how the caribou types are structured in the Sahtú region has legal implications because boreal woodland caribou are listed as threatened by the federal Species at Risk Act (SARA) and the territorial Species at Risk (NWT) Act and thus warrant specific protection and recovery measures (Environment Canada 2012, Species at Risk Committee 2012). The development of a national recovery strategy and subsequent action plans for boreal woodland caribou conservation has been delayed, in part, because of the complex intraspecific variation that characterizes the species. To date most range boundaries include a poor understanding of long-term caribou movements, gene flow, and genetic divergence. Current research examining zones of contact and introgression among caribou subspecies aims to help define evolutionarily significant conservation, management, and population units (Weckworth et al. 2012, Colson et al. 2014, Røed et al. 2014, Klütsch et al. 2016); however, alternative sources of knowledge are rarely considered in the context of caribou ecology and conservation (but see O'Flaherty et al. 2008, Mager 2012, Polfus et al. 2014).

Fig. 1. The Sahtú region of the Northwest Territories, Canada, includes the overlapping ranges of three types of caribou (Rangifer tarandus): tọdzı (boreal woodland caribou; striped green), rekwę (barren-ground caribou; blue), and shúhta repé (northern mountain caribou; stippled orange). Small black dots represent locations of caribou fecal, tissue, and blood strip samples collected in the Sahtú Region and Nahanni National Park Reserve, Northwest Territories, Canada.

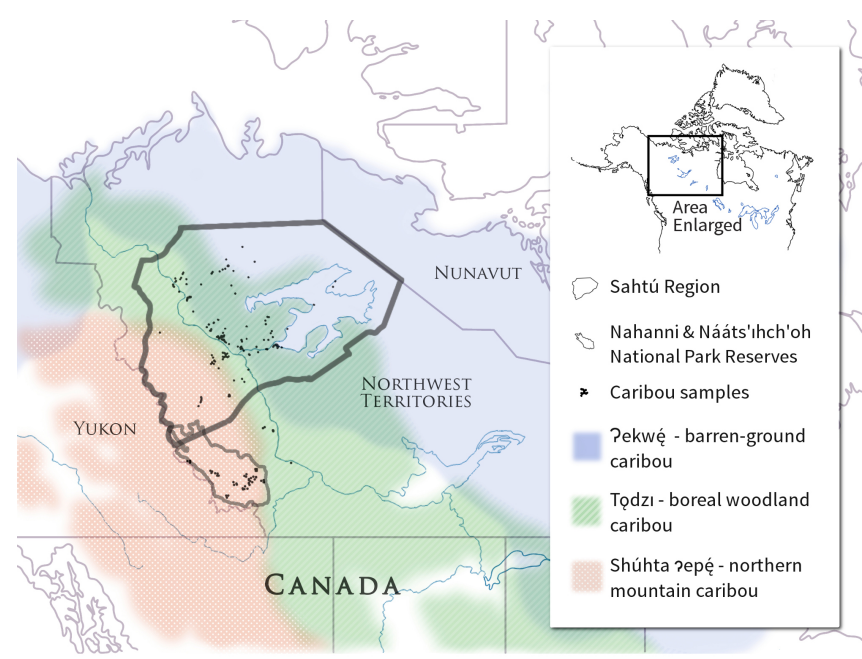

Challenges to the classification of Rangifer present an ideal opportunity to use multiple knowledge sources to develop a more thorough and complete understanding of caribou population organization and variation (Crandall 2009). Knowledge that arises from indigenous people's ecological relationships is often referred to as traditional knowledge (TK) and encodes ways of knowing and describing environmental diversity (Hunn 2006). Although significant scholarly work has defined and critiqued the mechanisms, functions, cultural significance, and cognitive basis of biological classifications (Berlin 1973, Atran 1990, Lakoff 1990, Ingold 2000, Newmaster et al. 2007), there remains space for a more practical consideration of the substantive knowledge indigenous people hold about their environments in the context of conservation (Fraser et al. 2006). Traditional knowledge is a product of a dynamic process of individual engagement with 
ecosystems that reflects people's capacity to respond to a constantly changing environment (Berkes 2012). Traditional knowledge is neither static nor antiquated. Processes and institutions guide the production and legitimation of TK as part of a living practice that is constantly updated and renewed (Ingold 2000, Davidson-Hunt 2006). For the purpose of this paper we make the distinction between science and TK. We find it useful not to conflate the two knowledge traditions because the procedures that make up science arose from their own particular social-institutional history and bringing science and TK together requires substantive interpretive and heuristic procedures (Scott 2011). Thus, TK has the potential to provide robust descriptions of species variation that can add value to our understanding of coupled human and natural systems (Fraser et al. 2006, Liu et al. 2007).

Language is one medium by which TK is transmitted and expressed and in the Sahtú it is crucial to the interpretation, organization, and articulation of biodiversity (Lakoff 1990, Basso 1996, Hey 2001, Evans 2012). Knowledge holders often need to speak their own language (rather than English) to accurately describe complex components of TK. Examining multiple language systems in parallel allows for descriptions that have the potential to reach beyond one dominant biological classification structure (Davidson-Hunt et al. 2005, Stronen et al. 2014). Languages can express meaning in different ways. This is partially due to the fact that what must be obligatorily expressed in one language need not be obligatorily expressed in another, and thus the structure of the language can implicitly and explicitly affect how speakers engage with the world and influence memory, perception, and categorization (Markman and Hutchinson 1984, Harrison 2007, Deutscher 2010, Boroditsky 2011). Indigenous languages can provide refined and multifaceted descriptions of biodiversity (Hale et al. 1992, Newmaster et al. 2007), alternative ways of examining and relating to nonhuman animals (Ingold 2011, Miller and Davidson-Hunt 2013), and insight into the underlying processes that create biological structure and drive patterns of biodiversity (Ragupathy et al. 2009, Gavin et al. 2015).

To achieve effective conservation outcomes there is a need to explicitly explore, not only variation itself, but the biocultural forces that shape variation and the relationships people establish within evolutionary systems (Gavin et al. 2015). The concept of biocultural diversity emphasizes the reciprocal relationships and overlapping realms of cultural, biological, and linguistic diversity and the many compelling similarities between languages and species as essential units of culture and nature (Loh and Harmon 2014, Gavin et al. 2015). Recent investigations into the link between biological and cultural diversity have generated important discourse concerning the vital role of TK, language, and diverse knowledge systems in conservation and environmental management (Davidson-Hunt et al. 2012, Gavin et al. 2015).

Land claim settlements across the Northwest Territories have introduced new institutions and governance structures that have the potential to reframe policies influencing lands and resources. In the Sahtú region, Dene and Métis representatives from local Rehdzo Got'lnę (Renewable Resources Councils; RRCs) recently passed a resolution that called for a renewed commitment to adopt $\mathrm{TK}$ and the laws of the Dene people as the guiding principles for caribou research and management. To support the ambitious goals set forth by the communities, we collaboratively developed a research approach to explore questions about caribou variation and differentiation using both traditional and scientific knowledge. We focused on łeghágots'enetę "learning together" and acknowledged the complex nature of caribou as part of a dynamic bioculturally diverse system. Our ultimate goal was to support the practices that enhance people's continued relationships with caribou and promote socially and culturally appropriate solutions to the complex challenges facing caribou conservation. In this article, we discuss the potential for population genetics and TK to deepen our understanding of caribou variation and the robust relationships that people maintain with the species.

\section{METHODS}

\section{Study area}

The Sahtú region surrounds Great Bear Lake and encompasses $280,238 \mathrm{~km}^{2}$ of central Northwest Territories (NWT), Canada (Fig. 1), an area larger than the United Kingdom with a population of just over 2300 people (Statistics Canada 2012). The current regional boundaries were defined by the Sahtú Dene and Métis Comprehensive Land Claim Agreement that concluded in 1993. Dene people have lived in the region for thousands of years and share a common Sahtú Dene or Athapaskan/North Slavey cultural and linguistic history (Helm et al. 2000). There are currently five communities in the region: Délınę, Tulit'a, Norman Wells (Tłegǫ́hłl), Fort Good Hope (Rádelı Kóé), and Colville Lake (K'áhbamí Túé). Until the establishment of local government administrations and day schools during the postWWII period, Dene and Métis peoples led a nomadic existence in a seasonal harvesting cycle (Abel 2005). Despite the shift to a more sedentary way of life in the communities, Sahtú Dene and Métis maintain strong cultural and social-ecological relationships with the land and wildlife (Andrews et al. 2012a,b, McMillan and Parlee 2013, Harnum et al. 2014).

There is considerable variation within the Dene language that is spoken across the region, with varieties differing primarily by sounds and vocabulary (Rice 1989). Defining linguistic subgroups of Athapaskan languages is challenging because of historical intergroup communication and overlapping distributions that result in borders that in many ways resemble the ambiguous boundaries of species classifications (Krauss and Golla 1981, Helm et al. 2000). Language in the Sahtú region varies based on specific family roots and community social linguistic units. The main dialect groups are flexible and differ from each other more or less based on family groups and historical relationships: 1 . K'áálo (Willow Lake), Dəoga (Mackenzie River), and Shúhta (Mountain) spoken in Tulit'a; 2. Sahtú (Bearlake) spoken in Délınę; 3. K'áhsho (Hare) and Dala spoken in Fort Good Hope and Colville Lake, respectively (Harnum et al. 2014). Fluency in Dene language varies greatly across generations and communities. Elders retain the highest rates of fluency while young people are less likely to speak Dene as their first language. In the Sahtú, an estimated 1000 people are able to converse in the language. In 2014, Délıne reported the highest percent of indigenous people over the age of 15 who could speak Dene (78\%; NWT Bureau of Statistics 2014). 
The subarctic landscape of the Sahtú is diverse and encompasses four major ecozones: southern arctic, taiga plains, taiga shield, and taiga cordillera. At treeline, north of Great Bear Lake, tall shrub tundra ecosystems of dwarf birch (Betula glandulosa) and willow (Salix spp.) transition into boreal forest dominated by conifers: black spruce (Picea mariana), tamarack (Larix laricina), and white spruce (P. glauca). Deciduous stands of trembling aspen (Populus tremuloides), paper birch (Betula papyrifera), mountain alder (Alnus tenuifolia), and willow are found in drier and warmer sites. Lichens, mosses, dwarf birch, cotton-grass (Eriophorum spp.), Arctic white heather (Cassiope tetragona), Labrador tea (Ledum groenandicum), and multiple Dryas and Vaccinium species make up the ground cover. Dynamic fire cycles establish and control energy flows in the boreal forest. The region contains zones of continuous, extensive discontinuous and intermediate discontinuous permafrost (Heginbottom 2000). The climate is typified by long, cold winters and short, warm summers. Precipitation is low and restricted by a rain-shadow in the Mackenzie Valley, which generates milder climates than those to the east and west (Dyke 2000). Mean temperature in Norman Wells is $-27.4^{\circ} \mathrm{C}$ in January and $16.7^{\circ} \mathrm{C}$ in July (Kokelj 2001).

The Dehcho (Mackenzie River) that flows into the Beaufort Sea dominates the hydrology of the region. Its watershed is the largest in Canada and covers approximately 1.7 million $\mathrm{km}^{2}$ (Kokelj 2001). Sahtú Deh (Great Bear River), a major sub-basin, flows from an outlet in Great Bear Lake near Délınę over low relief landscape and enters Dehcho at Tulit'a. West of Dehcho, the Mackenzie and Selwyn Mountains form the northernmost extension of the Rocky Mountain range and extend along the Yukon/NWT border from British Columbia to the Peel River plateau. Climatic zones vary according to the elevation gradient that ranges from $2972 \mathrm{~m}$ (highest peak) to foothills between 200 $-800 \mathrm{~m}$. Major tributaries flowing from the mountains into Dehcho include Begáádá (Keele), Nógha Chılıne (Carcajou), and Fahfá Nılı̨né (Mountain). The Norman Range and Franklin Mountains, which parallel the east side of Dehcho from Fort Good Hope to Wrigley, form a series of steep bedrock ridges and plateaus with elevations of $\sim 1000 \mathrm{~m}$ (Morgan and Anderson 2013). The region has extensive karst formations including prominent sinkholes, caves, dry valleys, and gorges (Ford 2008).

Ungulates in the region include caribou, moose (Alces alces), muskox (Ovibos moschatus), mountain goats (Oreamnos americanus), and Dall sheep (Ovis dalli). The large mammal predator community consists of grizzly bears (Ursus arctos), black bears ( $U$. americanus), wolverines (Gulo gulo), wolves (Canis lupus), and Canada lynx (Lynx canadensis).

\section{Research design}

Our community-collaborative research project was developed and implemented within the current institutional and political structures of the Sahtú Land Claim and the Mackenzie Valley Resource Management Act (1998). Under this political structure the ?ehdzo Got'lnę Gots'ę Nákedı (Sahtú Renewable Resources Board; SRRB) and the five local RRCs of the Sahtú Region are responsible for managing renewable resources in the region including wildlife and habitat. The research project initiated a collaborative partnership between the SRRB, RRCs, university researchers, and the NWT Department of Environment and Natural Resources (ENR). We developed partnerships with key knowledge holders, elders, and an advisory group with support from the formal institutional structures. In September 2012, the Sahtú RRCs passed a joint resolution supporting the adoption of TK and Dene law as essential components of caribou research. Our research project is a direct outcome of the resolution and was designed to support the initiatives proposed by communities in line with the principals of community-based participatory research frameworks and methodologies (Appendix 1; Hall 1979, Ferreira and Gendron 2011).

Our research included community members in all phases of the research process and created an open and transparent dialogue between scientific and traditional knowledge (Cruikshank 1981, Cornwall and Jewkes 1995). We prioritized łeghágots'enetę "learning together" and knowledge generation in an attempt to develop a richer, culturally respectful, and relevant understanding of caribou variation. The principles and protocols governing the research were covered by a multiyear research license from the Aurora Research Institute (15217, 15443, and 15597), wildlife research licenses from ENR (WL500104, WL500307), and a University Ethics Protocol (J2012:202).

In December 2012, we held research planning meetings in Norman Wells, Fort Good Hope, Tulit'a, and Délınę to discuss the project and plan for winter field work. Discussions facilitated the development of research priorities, research questions, and appropriate methods for the current and future monitoring of caribou populations. In January 2013, we held a series of RRC and public meetings to plan for winter sampling, build awareness for the program, and train community members in sampling techniques. We developed a Memorandum of Understanding with each RRC to confirm the governing principles of the research, budgets, research methods, intellectual property rights, and administration of the project. Subsequent RRC meetings were held in each community (including the addition of Colville Lake) to continue to guide the research during the winters of 2013 and 2014

In alignment with our approach of łeghágots'enete "learning together" we prioritized opportunities that allowed for the establishment of collaborative relationships between an interdisciplinary group of community researchers, local experts, and academic researchers (discussed in more depth in Appendix 1). We promoted ongoing communication with the public through outreach and relationship building in the communities. Local experts shared knowledge about caribou histories, movements, and identities during formal and informal interactions on the land. The knowledge helped to guide sample collection and identified concepts and ideas that were discussed in depth at focus group meetings, with the advisory group, and among coauthors. All community participants received honoraria for their time.

\section{Focus group meetings}

We held focus group sessions (Agar and MacDonald 1995, Morgan 1996, Berman and Kofinas 2004) to build a comprehensive understanding of the origin, dynamic interactions, and spatial structure of caribou in the Sahtú region. Workshops lasted between one and two days. Three to 10 local experts, selected in partnership with the local RRCs, participated in five focus group sessions held in each of the communities (total 39 people) in April of 2013. Focus group participants had extensive firsthand knowledge of caribou populations in the 
region. Interpreters helped to develop appropriate metaphors to describe genetic concepts in ways that resonated with community members. We found that simultaneous interpretation was often unsuccessful when explaining complex scientific topics. Instead, we more often used sequential interpretation, which allowed more time for ideas to be heard and understood (many participants were bilingual). We also worked with community researchers and interpreters to build a robust understanding of Dene concepts and avoid back-translations from English. Focus group meetings included significant discussions in Dene language.

At meetings we provided an overview of the research process and described the methods and preliminary results. We documented information through word maps, flow charts, diagrams, geographic maps (Google Earth 7.1.5.1557), and note taking. We digitally audio-recorded meetings with participant consent. Consistent with the iterative nature of our research process, we concluded focus group meetings with a discussion of how the project could be improved. Key sections of the meetings were later translated and transcribed by local language specialists in English.

\section{Genetic sampling}

Community members, researchers, collaborators, and industry monitors collected caribou fecal pellets noninvasively during the winters of 2013 and 2014 by gathering frozen pellet piles found on the snow in plastic bags. In general, hunters and trappers collected samples while traveling on skidoo trails, winter roads, seismic lines, and traditional trails during normal on-the-land activities. The sampling area represented the range of all three types of caribou in the region. We encouraged community members to help with sample collection during outreach at public meetings, through promotional posters, regional newspaper stories, on local radio, and in Facebook posts. Community members received a $\$ 25$ gift card for gas at a local gas station for each caribou fecal pellet sample they provided. The RRCs and Norman Wells ENR staff oversaw sample collection, data entry, and gift card distribution. Collaborations with industry partners also allowed for targeted sampling by helicopter to locate areas of caribou activity (tracks, cratering, etc.) during the winter of 2013. In April 2014, we spent an additional three days flying by helicopter with participants selected in collaboration with the RRCs of Fort Good Hope, Tulit'a, and Délınę to collect scat samples and fill sampling gaps. We also collected muscle tissue samples and blood strip samples from hunted animals in collaboration with a caribou health monitoring study (Brook et al. 2009). Finally, we included caribou fecal samples collected in Nahanni National Park Reserve in the southern Mackenzie Mountains through collaborations with Parks Canada.

\section{Microsatellite genotyping}

We followed microsatellite genotyping protocols that had been established as part of a long-term caribou genetic database to ensure the production of high quality genetic profiles (Ball 2007, Ball et al. 2010, Galpern et al. 2012a, Hettinga et al. 2012, Klütsch et al. 2012). To isolate DNA we swabbed and amplified the mucosal layer covering the caribou fecal pellets. We genotyped a panel of nine microsatellite loci (BM848, BM888, MAP2C, RT5, RT6, RT7, RT9, RT24, and RT30; Bishop et al. 1994, Wilson et al. 1997, Cronin et al. 2005). In May 2013 swabbing took place in Norman Wells where we worked with local students and trained technicians to build capacity in the communities and to continue to foster collaboration during the research process. Subsequent genetic analysis took place at Trent University. Extraction protocol followed Ball (2007) and profiling procedures can be found in Galpern et al. (2012a) and Klütsch et al. (2016). Electropherograms were scored by at least two individuals with GENEMARKER v. 1.9.1 (SoftGenetics, LLC) to determine allele sizes. Samples included in the final dataset had a minimum of eight successfully amplified loci. We used AlleleMatch 2.5 (Galpern et al. 2012b) to screen profiles for genotyping errors, remove duplicate profiles, and identify the number of individual caribou sampled. Only one sample from each individual caribou was included in subsequent analysis.

\section{Mitochondrial DNA (mtDNA) sequencing}

Genetic analysis of nuclear and mtDNA (mitochondrial DNA), larger sample sizes, and improved analytical methods have influenced our understanding of caribou taxonomy and evolutionary history in North America (McFarlane et al. 2009, Klütsch et al. 2012, Mager et al. 2013, Yannic et al. 2014). Specifically, analysis of mtDNA has revealed two distinct phylogenetic groups of caribou that represent separate northern and southern glacial refugia during the Pleistocene. Many of the boreal woodland caribou in the southern Canadian provinces originated south of the Laurentide ice sheet that covered most of present-day Canada (North American lineage; NAL), while barren-ground caribou likely originated in the northern unglaciated refugium of Beringia and the Canadian high arctic (Beringian-Eurasian lineage; BEL, McDevitt et al. 2009, Klütsch et al. 2012) To examine phylogeographic structure we amplified and sequenced a 429 bp mtDNA control region fragment using the primers: L15394:5' - AAT AGC CCC ACT ATC AGC ACC C - $3^{\prime}$ and H15947:5' - TAT GGC CCT GAA GTA AGA ACC AG - 3' (Flagstad and Røed 2003). Only samples from individual caribou were sequenced. We followed lab procedures outlined in Klütsch et al. (2012). We used the program BioEdit 7.2.5 (Hall $1999)$ to check and align sequences. Mutations were manually double-checked and all newly identified haplotypes were resequenced to confirm their identity.

\section{Genetic analysis}

We used the program Structure 2.3.4 (Pritchard et al. 2000) to test for population subdivision and assign individual caribou to inferred subpopulations (Falush et al. 2003). We performed five runs with 1,000,000 burn-in iterations and 10,000,000 Markov chain Monte Carlo (MCMC) repetitions. We varied the number of $\mathrm{K}$ between 1 and 15 under the admixture model with correlated allele frequencies, and specified no a priori models of subpopulation structure. We plotted the mean and variance in likelihood per K using Structure Harvester v0.6.94 (Earl and vonHoldt 2012). We found the average individual membership coefficients across the five iterations using the programs CLUMPP 1.1.2 (Jakobsson and Rosenberg 2007) and DISTRUCT 1.1 (Rosenberg 2004). We mapped the structure output by interpolating the average probability assignment score using the inverse-distance-weighted interpolation in ArcGIS 10.1 (ESRI, Redlands, California, USA) and confining the interpolation to sampled locations (Twomey et al. 2014).

We assessed genetic diversity by calculating genetic indices of the structure informed populations with GenAlEx 6.501 (Peakall and Smouse 2006, 2012) and HP-Rare 1.1 (Kalinowski 2005). We 
tested for significant deviations from Hardy-Weinberg equilibrium (HWE) and linkage disequilibrium (LD) per locus and population using GenePop 4.2 (Rousset 2008). We used SPAGeDi 1.5 (Hardy and Vekemans 2002) to test the microsatellite pairwise differentiation with $\mathrm{F}_{\mathrm{ST}}$ and $\mathrm{R}_{\mathrm{ST}}$ and used ARLEQUIN 3.5.2.2 (Excoffier and Lischer 2010) to test the mtDNA pairwise differentiation $\left(\Phi_{\mathrm{ST}}\right)$ and analysis of molecular variance (AMOVA; see Klütsch et al. 2016 for further details).

\section{Collaborative analysis}

We analyzed information shared during focus group sessions using a combination of thematic analysis and modified grounded theory methods to identify important concepts and themes (Glaser and Strauss 1967, Bernard 2002, Berman and Kofinas 2004). We used the program NVivo (QSR International Pty Ltd. Version 10) to code meeting notes, transcripts, and other TK reports and publications. Hierarchical categories emerged through the process of coding and were developed into potential themes as the ideas became more concrete through repeated identification. To support a collaborative production of knowledge we facilitated a process for coanalysis of the TK and genetic data. With the help of RRCs, individuals were selected from all Sahtú communities for their expertise and interest in participating in an advisory group. The advisory group's role was to guide the project, ensure that Dene knowledge was properly and respectfully interpreted, and provide the TK context needed to help accurately interpret the genetic data. We discussed TK themes, language, and genetic results in two separate 3-day meetings to clarify and develop important concepts (Fig. A1.1 and A1.2). Our first advisory group meeting, held in June 2014, included seven participants who helped plan and select additional elders to participate in a follow-up meeting. The meeting was transcribed and coded. The second meeting was held in February 2015 and included 11 participants.

We employed what we call a language-based methodology by working to elucidate conceptual Dene TK needed to ground the concepts and themes. Elders often requested to speak only in Dene language when discussing TK. Walter Bayha uses a translation of the teachings of his Shúhtagot'inę grandfather, Joseph Bayha, to explain this affinity: "Our history is written on the land. The language comes from the land." Dene knowledge holders stressed the importance of respecting dialect differences and were very careful to avoid making assumptions about how speakers of other dialects would express a word or concept. The advisory group agreed that in general it is best to defer to Dene words in a dialect with a direct relationship to the caribou population being discussed. In this paper, we generally use Shúhta (S) dialect when referring to caribou in the mountains and Sahtú/Délınę (D) dialect with respect to barren-ground caribou terminology. We also include K'áhsho (K) words where possible (Fig. 2).

The advisory group focused on key concepts and ideas from previous focus group meetings, TK literature, and publications. We used visual facilitation techniques to guide the advisors to expand on important topics and explain the genetic data. We paid special attention to clarifying Dene TK and descriptions of the types of caribou found in the Sahtú region as well as presenting our preliminary interpretation of the genetic data to help assess how appropriate our inferences were with respect to TK of caribou ecology in the region. Beyond the two formal meetings, several of the advisory group members have continued to guide the research, interpret genetic data, work on the details of Dene language translations, review drafts of manuscripts, copresent the research in schools and during public presentations, and coauthor this manuscript.

Fig. 2. Word descriptions and definitions in the Shúhta (S), Sahtú/Délı̨nę (D), and K'áhsho (K) dialects of the North Slavey language in the Sahtú region of the Northwest Territories, Canada.

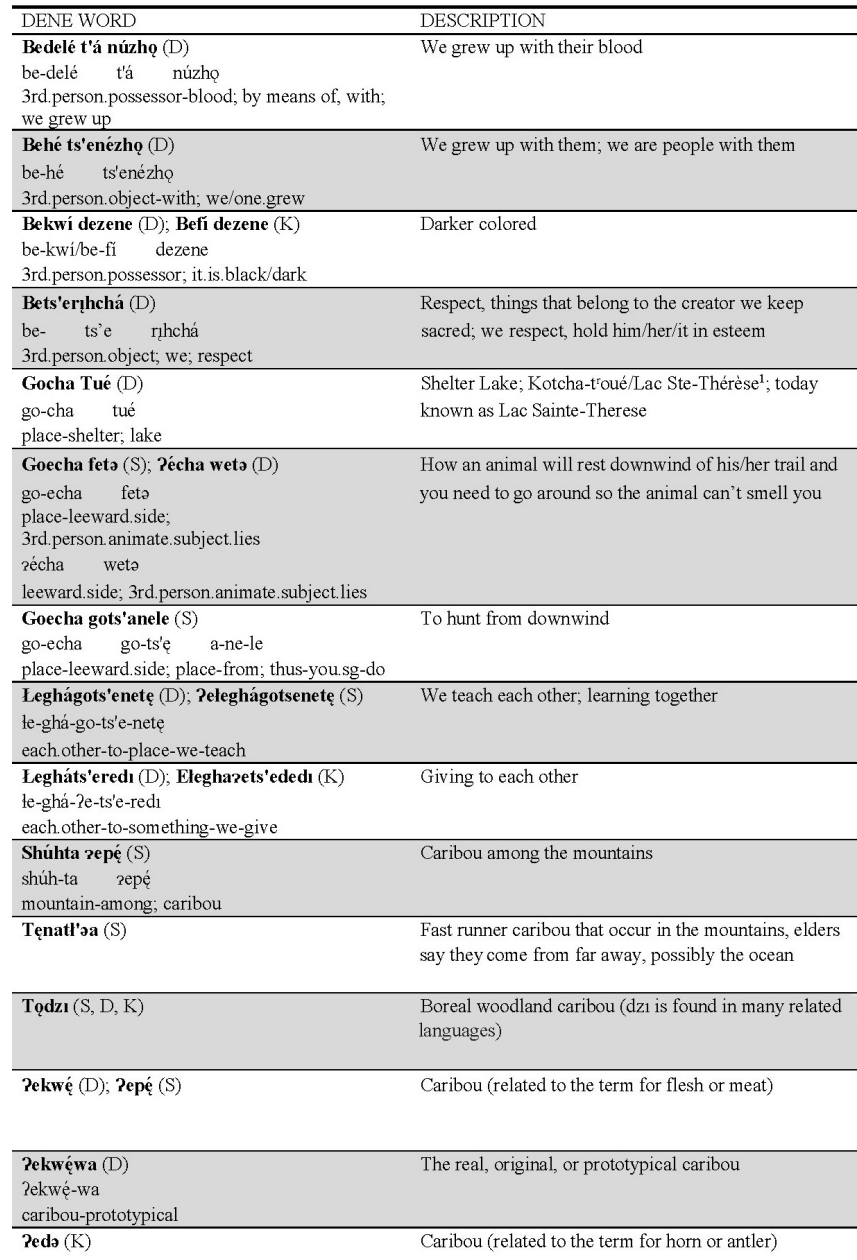

${ }^{1}$ Petitot (1893)

\section{RESULTS}

\section{Traditional knowledge}

During focus group meetings elders continually expressed their personal relationship with caribou as being crucial to understanding caribou knowledge. One example of this association was described by Alfred Taniton as bedélé t'á núzho (D) that translates to "we grew up with their blood" (Fig. 2). Alfred Taniton said, "we were raised with the blood from the caribou. In the past, the people have always survived because of the blood of the animals." The intimate interaction between human and nonhuman animals highlights how many indigenous people recognize the importance of their relationships with other beings on a daily basis. The concept behé ts'enézho (D) "we grew 
up with them," or as Walter Bayha translated, "we are people with them," further illustrates how Dene people relate to caribou as unique entities, capable of intelligence, identity, perception, selfawareness, rationality, and intentionality.

When Dene people relate to nonhuman animals autonomously they follow important Dene laws regarding bets'erchchá (D) "respect" and łegháts'eredı (D) "we give to each other." Dene people recognize that individual animals have unique perspectives that allow them to gain knowledge and intelligence in distinctive ways (Legat 2012). Elders repeatedly state that caribou are their own bosses and cannot (and should not) be controlled by people. Rather, Dene laws provide guidance for mutual respect and honor that require that Dene take care of caribou so that caribou will reciprocally provide for them. Gordon Yakeleya stated the following:

It's very important that we look after the animals, we have to have respect for them. There's a reason why they do what they do. They want to survive like we want to survive. It's the same thing. That's what my mom and dad always said: "Animals are like human beings." They do everything for a reason, just like we do. Like we go to store, they get food for the whole winter. They raise their young ones and teach their young ones. We do the same thing.

Fundamental to the Dene relationship with caribou is a profound knowledge of caribou morphology, behavior, and habitat preferences. Dene people identify three main types of caribou in the region: shúhta repé (S) "mountain caribou," rekwé́/zeda (D/ K) "barren-ground caribou," and tọdzı "boreal woodland caribou" (Fig. 2). Participants describe tǫdzı as bekwí dezene (D) "darker colored/having a dark head," larger and heavier than rekwé. Shúhta repé are identified by their large size and close association with the mountains. The caribou types can also be distinguished based on their tracks (size, shape, and the encoded behavior) and their general location. Though the ranges of todz1 and rekwé/redə $(\mathrm{D} / \mathrm{K})$ overlap in many areas during the winter, knowledgeable hunters and elders are able to distinguish between the types. For example, Gabe Kochon of Fort Good Hope described a situation where he once saw a very large male todzı (that was a dark color) in the center of a group of female barrenground caribou during rut many years ago. Hunters have even reported being able to distinguish types by the taste of the meat. Interestingly, some Shúhtagot'lnę elders describe a fourth type of caribou called tęnatł'əa (S) "the fast runners" that live in the Mackenzie Mountains, migrate long distances, and are identified by particular morphological markings.

Although there are dialect differences in the words used to refer to barren-ground caribou, the classificatory term todz1 "boreal woodland caribou" is shared across the region and mirrors the caribou population's distribution. The word todz1 is also found in the Tłcho language of central NWT and the second part of this word, dz1, is commonly associated with Athapaskan caribou words and is found in many related languages including $T t_{c} \mathrm{ch}$, Dene Sưłıné, and languages of the Yukon, Alaska, and British Columbia. Further, in Délınę the word rekwęwa (D) can be used when discussing different types of caribou and translates to "the real (or the original/prototypical) caribou," which links the language with the histories of the caribou. Gabe Kochon of Fort Good Hope also explained through translation that the "regular" caribou have always been in the north (living in the barren-land north of Fort Good Hope) whereas tǫdzı probably had a different origin.

Knowledge of differences in behavior between different caribou types is essential to successful hunts. Dene hunters describe how todz1 react much more strongly to the presence of humans than rekwé or shúhta repé. Focus group participants explained that to successfully hunt todz1 it is necessary to anticipate the animal's behavior. They used the Dene phrase goecha fehto (S) to describe a situation in which a todzı will loop back on his or her own trail so he/she can rest (lie down) in a sheltered area downwind from his/her path and thus be alerted to the scent of potential predators that might be following his/her tracks. The hunter must react by predicting the caribou's behavior and looping around behind to ensure that the animal can't smell the hunter before they can take a shot. In Dene, this can be described as goecha gots'anele (S) "to hunt from downwind." This behavior is also described for moose, but not zekwée or shúhta zepé. Interestingly, a similar word is found in the place-name Gocha Túe (D) that was first translated in the 1860s by French Oblate missionary Father Émile-Fortuné Petitot as Shelter Lake (and which he renamed Lac Ste-Thérèse/Lac Sainte-Therese; Petitot 1893). Walter Bayha was able to use Petitot's translation to uncover the obscured meaning of the place-name through the word "gocha" and the sheltered snowdriftless characteristics of the lake where he spent time when he was young.

Monitoring caribou population fluctuations has been imperative to Dene survival for millennia (Beaulieu 2012). Over time, significant migrations and range-shifts have occurred between caribou groups. Dene descriptions of large-scale caribou movements help explain current caribou distribution, temporal patterns, and can be used to predict future movements. Uncommon movements of barren-ground caribou herds that winter around Great Bear Lake are often recalled and discussed because they can influence caribou health and hunting methods. For example, Gordon Yakeleya remembers how in the winter of 1988 barren-ground caribou migrated all the way down to K'áálo Tué (Willow Lake) near Tulít'a and displaced resident tǫdzı. In Fort Good Hope, elders speak about a large herd of caribou that crossed the Dehcho and headed into the foothills of the mountains many years ago. Gabe Kochon said that they never saw the entire herd return or migrate back across the river. He related the following in Dene language:

There was a lot of them, I have witnessed the caribou crossing ... ice, even though it was broken up, there was lots of them... Many years ago, the caribou crossed to the other side.... They have been gone a long time and people are saying that they have become lots again and they have been using that area for calving ... This is according to the elders and they also say that they will never disappear.

\section{Microsatellites}

We collected caribou scat samples from the Sahtú region and Nahanni National Park Reserve with the cooperation of $\sim 100$ community members and project collaborators including grade school and high school students, hunters, trappers, environmental monitors, researchers, and industry partners. We obtained 1036 caribou fecal samples, 96 caribou tissue samples, and 16 caribou blood strips from localities across the Sahtú region and Nahanni 
Table 1. Genetic diversity estimates, averaged across nine microsatellite loci, for the three major caribou (Rangifer tarandus) groups identified by structure analysis: number of samples (N), number of alleles (NA), allelic richness (AR), private allelic richness (ARP), observed (HO) and expected (HE) heterozygosity, FIS estimates, and standard errors (SE) for each estimate.

\begin{tabular}{lcccccccccc}
\hline \hline Group & $\mathrm{N}$ & $\mathrm{N}_{\mathrm{A}}$ & $\mathrm{SE}$ & $\mathrm{A}_{\mathrm{R}}$ & $\mathrm{A}_{\mathrm{RP}}$ & $\mathrm{H}_{\mathrm{O}}$ & $\mathrm{SE}$ & $\mathrm{H}_{\mathrm{F}}$ & $\mathrm{SE}$ & $\mathrm{F}_{\mathrm{IS}}$ \\
\hline Barren-ground & 123 & 15.1 & 1.20 & 14.97 & 2.50 & 0.84 & 0.013 & 0.87 & 0.010 & 0.035 \\
Boreal woodland & 171 & 12.0 & 1.43 & 11.26 & 1.05 & 0.79 & 0.023 & 0.79 & 0.023 & 0.005 \\
Mountain & 260 & 17.1 & 2.93 & 14.38 & 2.29 & 0.82 & 0.014 & 0.84 & 0.011 & 0.031 \\
\hline
\end{tabular}

National Park Reserve (Fig. 1). A subset of these samples were analyzed and 996 were successfully amplified at $>8$ loci and included in the analysis. We identified 555 individual animals (47\% female, $41 \%$ male, and $12 \%$ unknown gender). Missing data in the microsatellite dataset was low $(3.43 \%)$. Average number of alleles per locus was 20 across all individuals (Table A2.1). We did not find evidence for systematic deviations from $\mathrm{HWE}$ in specific populations (4/27 cases were significant after Bonferroni correction) or LD (no cases significant).

Structure analysis identified $\mathrm{K}=2$ as the highest level of substructure (using the $\Delta \mathrm{K}$ criterion) that corresponded to a boreal woodland group and a mountain/barren-ground group (Fig. A2.1). Further finer-scale structure of $\mathrm{K}=3$ corresponded with an additional split between mountain and barren-ground (Fig. 3, Fig. A2.2). These partitions were largely concordant with the TK on caribou types in the region, supporting an ecological foundation for three inferred groups that represent clusters of (1) barren-ground caribou; (2) boreal woodland caribou; and (3) mountain caribou (Fig. 3). The barren-ground population had the highest levels of allelic diversity and heterozygosity (Table 1). Pairwise comparisons between groups $\left(\mathrm{F}_{\mathrm{ST}}\right.$ and $\left.\mathrm{R}_{\mathrm{ST}}\right)$ indicated low levels of differentiation, though the boreal woodland group was the most differentiated from the other two types (Table A2.2, A2.3).

\section{mtDNA}

We identified 69 mtDNA control region haplotypes from 337 individual caribou (Table 2, Fig. A2.3). We fit the mtDNA data into the well-resolved phylogeny of NAL and BEL (see Klütsch et al. 2012, 2016). Unlike the nuclear markers (microsatellites) that showed intraspecific divisions between types at the regional scale, the phylogenetic mtDNA analysis revealed that caribou of the Sahtú belong predominantly to the BEL (96.7\% Beringian). However, very few haplotypes $(n=12)$ were found in more than one of the three clusters identified by structure (Fig. A2.3). Most haplotypes were nonoverlapping, signifying long-standing diversification among the types. We identified only 3 NAL haplotypes (in 11 caribou) in the study area, most belonging to haplotype $50(n=9$ boreal woodland caribou $)$ in the Sahtú region (Fig. A2.3). This was an especially surprising result and suggests that boreal woodland caribou in the northern extent of their range are distinct from more southern boreal woodland caribou that generally belong to the NAL (Klütsch et al. 2012). Pairwise comparisons using the mtDNA data $\left(\Phi_{\mathrm{ST}}\right)$ were low but significant (Table A2.4) and showed the strongest differentiation between boreal woodland and mountain, and barren-ground and mountain, which may suggest that the mountain group have been historically isolated. The AMOVA of the three groups revealed that $\sim 14 \%$ of the mtDNA genetic variation was found among populations (Table A2.5).
Fig. 3. We analyzed microsatellite data from caribou (Rangifer tarandus) genetic samples collected in the Sahtú region and Nahanni National Park Reserve of the Northwest Territories, Canada from 2012 to 2014. We used structure software to assign individual caribou to inferred genetic clusters. We found support for $\mathrm{K}=3$ populations (shown in bottom bar) that coincided with clusters of (1) barren-ground (blue), (2) boreal woodland (green), and (3) mountain (red). Vertical colored bars indicate the probability that an individual belongs to a certain group. We mapped the structure output using the inversedistance-weighted interpolation in ArcGIS and constrained the interpolation to the sampled locations.
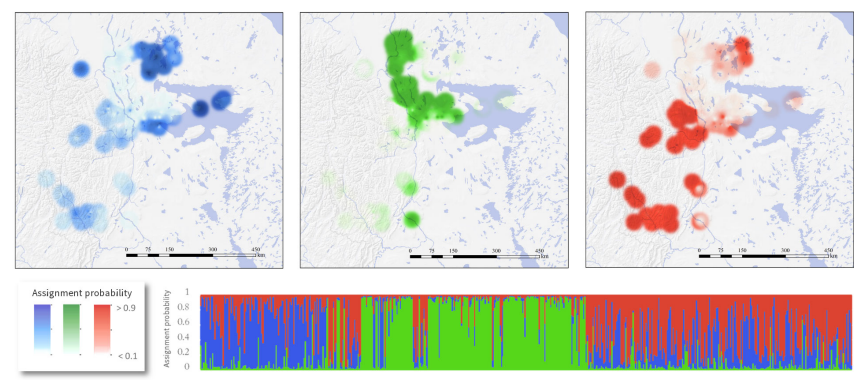

\section{Caribou spatial diversity}

Collection sites were distributed across the range of all types of caribou in the Sahtú region (Fig. 3) and were focused on traditional hunting areas in the mountains (along the Begáádá "Keele" and Nógha Chılıne "Carcajou" rivers, Tets'ehxe "Drum Lake," and "Canol Lake"), Nahanni National Park Reserve, the boreal forest in the Mackenzie Valley, and the winter-ranges of the Bluenose West (area surrounding K'áhbamí Túé "Colville Lake," Nilln Túé "Lac Belot" and Tashín Túé "Lac Des Bois") and Bluenose East (?ehdąla "Caribou Point" and around Délınę) barren-ground caribou herds.

Strikingly, the spatial distribution of the boreal woodland genetic cluster encompassed the known range of boreal woodland caribou and was restricted to the boreal forest of the Mackenzie valley (Fig. 3). Although the geographic cohesion was strong there was overlap with the two other clusters that demonstrates at least some level of intergradation between the types. It is well known that barren-ground caribou herds often overlap in distribution with the much less numerous boreal woodland caribou in the winter. However, as described above, knowledgeable hunters are able to distinguish between the types and this was also demonstrated by the genetic results. In the winter of 2013, Wilbert Kochon, a Colville Lake hunter, killed three caribou, which he 
Table 2. Haplotype (mtDNA) genetic diversity for the three major caribou (Rangifer tarandus) groups identified by structure analysis: number of individual caribou samples analyzed for mtDNA (N), number of samples assigned to the North American and BeringianEurasian haplogroup lineages $\left(\mathrm{NAL}_{\mathrm{N}}\right.$ and $\mathrm{BEL}_{\mathrm{N}}$, respectively), number of haplotypes in the NAL $\left(\mathrm{NAL} \mathrm{H}_{\mathrm{H}}\right)$ and $\mathrm{BEL}\left(\mathrm{BEL} \mathrm{H}_{\mathrm{H}}\right)$ haplogroups, nucleotide diversity $(\pi)$, and gene diversity (GD) with standard deviations (SD).

\begin{tabular}{lcccccccccc}
\hline \hline Group & $\mathrm{N}$ & $\mathrm{NAL}_{\mathrm{N}}$ & $\mathrm{BEL}_{\mathrm{N}}$ & $\mathrm{NAL}_{\mathrm{H}}$ & $\mathrm{BEL}_{\mathrm{H}}$ & $\pi$ & $\mathrm{SD}$ & $\mathrm{GD}$ & $\mathrm{SD}$ \\
\hline Barren-ground & 93 & 1 & 92 & 1 & 37 & 0.0170 & 0.0090 & 0.9385 & 0.0165 \\
Boreal woodland & 110 & 9 & 99 & 1 & 12 & 0.0192 & 0.0100 & 0.844 & 0.0195 \\
Mountain & 134 & 1 & 133 & 1 & 31 & 0.0213 & 0.0110 & 0.9174 & 0.0144 \\
\hline
\end{tabular}

identified as tǫdzı, in an area where overlap with barren-ground animals was clearly occurring (based on tracks and reported sightings). Later, genetic analysis of tissue samples from the three caribou indicated they clustered with the boreal woodland group (average probability of assignment was 0.942 to the boreal woodland cluster). Interestingly, the few samples collected along the Mackenzie River near Nahanni National Park Reserve also clustered most strongly with the boreal woodland group (Fig. 3).

The spatial boundaries between the barren-ground and mountain clusters were less distinct, however the two groups generally occur in the vicinity of Great Bear Lake and within the Mackenzie Mountains, respectively (Fig. 3). Admixture is apparent throughout the Mackenzie Mountains as well as in the winterranges of the barren-ground herds. Interestingly, genetic analysis of the nine individual caribou sampled in the foothills of the mountains across from Fort Good Hope revealed that the group was genetically more similar to the barren-ground cluster than the mountain cluster. This coincides with the event described by Gabe Kochon about the historic movement of a large group of barren-ground caribou that crossed the Dehcho (Fig. A2.4).

\section{DISCUSSION}

In this study, we used a participatory approach to examine the biological variation of caribou populations of the Sahtú region of the Northwest Territories. Our community-collaborative research engaged local indigenous experts in all stages of the project and generated results that united Dene TK and population ecology. The participatory framework and iterative methods generated space for the refinement of collaborative research questions and allowed for a rigorous knowledge coproduction process. Our results provide evidence for genetic, linguistic, historical, phenotypic, and behavioral differentiation among the caribou types in the region. By recognizing the lived experience and TK of indigenous people we were able to develop more profound understanding of caribou ecology through which we were able to more accurately interpret the population genetic results. The genetic subpopulation structure corresponded to caribou types that are recognized and distinguished by Sahtú Dene and Métis people through their language. Detailed descriptions of tǫdzı "boreal woodland caribou," rekwę (D) "barren-ground caribou," and shúhta repé (S) "mountain caribou" denote quantifiable characteristics that categorize caribou in the region.

Dene concepts reflect ecological processes and relationships that bring the complexity of dynamic biocultural systems to light. The consistency of the word todzı across all Sahtú region dialects as well as the Tţcho region may suggest stability of the boreal woodland caribou phenotype in the region (though more research is needed to understand the contrasting pattern of variability in barren-ground nomenclature). Interestingly, we found substantial genetic differentiation between todzl and other caribou in the microsatellite genetic structure (Fig. 3). This is surprising because in other areas of North America where overlap among caribou types occurs, such clear delineation is not observed (Boulet et al. 2007, Klütsch et al. 2016, Pond et al. 2016). Thus, even in the face of extensive overlap and known mixing with barren-ground and mountain caribou populations (described by local Dene people), there are likely important adaptive traits that are necessary to retaining the behavioral and genetic characteristics of todzı. Mechanisms that can produce intraspecific population structure across continuous habitats include isolation by distance, divergence with barriers, drift after expansion, and local evolutionary adaptation (Puckett et al. 2015). In British Columbia, strong differentiation between wolf populations, which are capable of large dispersing movements, has been attributed to evolutionary adaptation to different ecological conditions (Stronen et al. 2014).

It is likely that the differentiation between todzı and other types of caribou in the region is due in part to ecological divergence. Dene knowledge of the association between todzı and the boreal forest is ubiquitous across the Sahtú region and was recorded as far back as the 1860s when Petitot documented Dene language and culture during his travels as a missionary (Moir 1998). Petitot's writings include descriptions of woodland caribou as loners that lived in the forests (Petitot 1893). Knowledge about differences in behavior among the types of caribou that occurred in different habitats was crucial to Dene survival. Historically, some of the most renowned Dene hunters were those who could successfully hunt and kill the large and widely dispersed tọdzı.

The more closely people associate with nonhuman animals, the more intimate and detailed the knowledge becomes (Brightman 2002). As Fred Sangris, a Yellowknives Dene, said, "We learn by being in the field, by being with ekwó [barren-ground caribou] all the time" (Sangris 2012:77). The historic caribou movements only observed by people with intimate knowledge of the environment also played an important role in refining our questions and methods. Gabe Kochon's detailed knowledge of historic caribou movements was crucial to our decision to collect samples from that specific region of the mountains. The information provided by the TK also allowed us to accurately interpret the genetic patterns that otherwise would have been difficult to understand, and supported the historic occupancy of distinct caribou groups in the region. 
Likewise, Alfred Taniton's description of growing up with the blood of the animals demonstrates how Dene people's survival and ways of life are linked with wildlife. Historically, people traveled across the land to hunt caribou for essential food, clothing, and tools and these practices are part of the expression of their identity. The depth of Dene people's relationship with caribou is revealed within Dene language. Dene language includes numerous descriptors that help facilitate communication and improve hunting success. Language can also provide clues to the histories of the caribou through descriptions like rekwéwa "the original or prototypical caribou" that is used in Délınę to refer to barren-ground caribou and inform alternative ways of classifying the relationships between caribou types. Although it is difficult to determine the exact time-frame reflected in the language, it is well established that Dene people have a substantial history with caribou, and barren-ground caribou in particular have been a crucial and relatively consistent resource for at least the last 8000 years (Gordon 2003, 2005, Andrews et al. 2012b, Beaulieu 2012).

The rich vocabulary of Dene caribou words points to the ease with which TK holders are able to describe complex behaviors and actions in Dene language that are difficult and unwieldy to depict in English. The use of words like goecha gots'anele in the context of hunting are understood by a relatively small portion of community members and require significant discussion in Dene language with elders, knowledgeable hunters, and interpreters to capture the detailed nuances in English. Conducting work in both Dene language and English was a consistent challenge. However, the dialogue and back and forth that was required to refine terms and concepts allowed us to come to a common understanding and identify deeper ecological connections that might not be apparent on the surface. As Walter Bayha pointed out, "If I didn't speak the language I wouldn't be able to make these connections." Thus, the examples we provide show that Dene language is deeply adapted to the environment in which it evolved and that a focus on Dene language, facilitated by the distinct disciplinary backgrounds of our research team, is one of the most important contributions of the collaborative work (see Appendix 1 for more information).

The complex nature of caribou substructure is further revealed by the differences between genetic marker types. Examining multiple markers concurrently can provide information about how phenotypic differences may be contributing to historical isolation and present patterns of gene flow (Wood et al. 2014). In the case of todzı in the Sahtú, the mtDNA haplogroups do not coincide geographically with the microsatellite markers. Similar divergence among markers has been shown in shovel-nosed snakes (Wood et al. 2014) and chipmunks (Good et al. 2008, Hird and Sullivan 2009). Surprisingly, results from the pairwise mtDNA analysis indicated that boreal woodland/todzı and barren-ground appear to be more closely related than either are to the mountain group (Table A2.4). Recent research suggests that mtDNA can introgress quickly, even at low levels of gene flow, while other loci remain resistant to introgression (Chan and Levin 2005, Hird and Sullivan 2009). Thus, one possible explanation for the phylogenetic pattern present in todz1 is potential historic introgression with northern Beringian lineage animals. Alternatively, the boreal woodland caribou/todzı phenotype may be an independent derivation from the BEL with little or no contribution from southern evolved boreal woodland caribou that carry NAL haplotypes. Analysis of competing evolutionary models will help identify and date divergence events and historical introgression between populations that have contributed to the current spatial genetic variation (e.g., Klütsch et al. 2016).

Variation below the species level is an important component of biodiversity because it provides the genetic variation required for incipient speciation and local genetic adaptation (Wood et al. 2014, Mee et al. 2015, Hamilton and Miller 2016). Cryptic intraspecific diversity, as is displayed between caribou ecotypes and subspecies (Pond et al. 2016), can be especially contentious because it is not always clear how to best identify, delimit, or maintain genetic lineage diversity (Mace 2004, Wood et al. 2014, Fitzpatrick et al. 2015). Further, from a purely scientific perspective, there can exist multiple valid interpretations because rules for finding discontinuity in genetic or spatial ecological data are at some level arbitrary. Combining multiple knowledge systems can help to provide complementary criteria for designating distinct units for conservation. We found this was the case in our study and used Dene TK to help us interpret the genetic statistical output (choosing $\mathrm{K}=3$ as the most biologically relevant inference that was supported by both the statistical analysis and TK). In doing so we use multiple knowledge sources to guide the translation of data to understanding. Thus, through a pluralistic approach we were able to demonstrate the ways that linguistic, TK, and genetic patterns corroborate each other and allowed us to identify criteria that can be used to identify and differentiate between groups of animals for biodiversity conservation.

Preserving evolutionarily significant diversity in caribou that is identified through the analysis of multiple genetic markers and TK is essential because caribou populations in the southern portions of their range face extirpation (Hebblewhite et al. 2010, Johnson et al. 2015). Further, recent research on loggerhead sea turtles (Caretta caretta) has shown that populations at the margins of the species range can be important reservoirs of genetic diversity and "contribute disproportionally to the adaptive potential and future viability of the population" (Stiebens et al. 2013:8). Thus, the genetic differentiation of todz1 and the rich TK on the unique attributes of the type provide evidence for their prioritization as an irreplaceable component of Canada's biodiversity. However, sustainable conservation strategies must find ways to maintain not simply the categorical entities (like subspecies) but rather the dynamic relations among peoples and species as the basis of bioculturally diverse systems.

The importance of supporting social-ecological relationships and processes is gaining momentum in conservation science (Gavin et al. 2015). Proponents of this viewpoint maintain that conservation priorities should be not be defined in relation to discontinuous species, but rather directed toward the protection of essential processes that create adaptive potential and sustain biological variation (Bowen 1999, Crandall et al. 2000, Moritz 2002, Eizaguirre and Baltazar-Soares 2014). This viewpoint acknowledges the subjectivity of species categories and highlights the importance of conserving the dynamic nature of functioning ecosystems. Strategies for identifying units for conservation that integrate multiple biological criteria, acknowledge the dynamic nature of intraspecific diversity, respond flexibly to specific circumstances, and adapt to differing situations are needed to cultivate evolutionary potential in a changing environment (Fraser and Bernatchez 2001). 
Similarly, ethnoecological explorations of the intrinsically adaptive nature of categorization systems place emphasis not on categorical entities (contents of categories such as species) but on defining elements of an ecosystem in relation to the other elements that surround them in time and space (Ingold 2011). As a consequence, more attention is given to an entity's function, its role in the larger spatial and temporal environment, rather than its intrinsic qualities that are devoid of context. Identifying important connections among ecosystem components allows the unpredictable emergent properties of a system to become apparent (Berkes et al. 2003, Ingold 2011) and can lead to improved conservation planning (Alcorn 1993, Fraser et al. 2006). For example, research suggests that TK classification systems can, in some cases, identify more taxa than science-based systems (Newmaster et al. 2007, Ragupathy et al. 2009) or be especially suited to identifying intraspecific diversity (Fraser et al. 2006). In the Sahtú, the description of a distinct group of caribou in the mountains known as tęnatł'əa warrants further study because they may harbor unique genetic diversity and could play an important role in intraspecific dynamics. Thus, the analysis of genetic variation in conjunction with the relationships indigenous people maintain with species has the potential to reveal complex patterns that would likely not be apparent when evaluated separately.

\section{CONCLUSION}

A renewed focus on multidisciplinary conservation frameworks demonstrates the importance of studying human and natural systems (social-ecological systems) in tandem (Liu et al. 2007, Collins et al. 2011, Bodin and Tengö 2012). By exploring indigenous people's relationships with caribou, which have been actualized through language, we developed new insights into the underlying processes that create structure and drive patterns of caribou biodiversity. We contend that indigenous languages provide an obvious place to ground research processes and build collaborations. Words can be used to strengthen people's relationship with local ecosystems and create appropriate and unifying dialogue. As Frederick Andrew affirmed, "The most important thing is to talk the old language and honor our ancestors that went before us." As a direct outcome of our research, the SRRB has made the decision to use the word todz1 in all official correspondence relating to boreal woodland caribou. The process of changing vocabulary has the potential to allow for the development of common-ground from which new relationships can move forward (Stevenson 1998). By recognizing the validity of other knowledge systems it is possible to broaden the worldview of the listener (Gavin et al. 2015). In doing so the world "becomes richer as our ability improves to view it from a variety of angles" (Cruikshank 1981:86).

Through the process of łeghágots'enete "learning together" we were able to embrace the synergies that come from the sometimes intangible process of knowledge expansion and develop comprehensive descriptions of caribou populations that reflect biodiversity. Our results point to the importance of assessing multiple criteria simultaneously when determining population boundaries and characterizing population structure. We found clear connections between Dene people's descriptions of caribou ecology and other domains of knowledge such as population genetics where connectivity and delineation of groups are central themes. Utilizing multiple methods has the potential to strengthen evidence-based decisions with respect to range mapping as part of the boreal woodland caribou range and action plans (Environment Canada 2012) and environmental assessments in response to potential shale-oil development in the region. At the national scale, our results provide guidance on the delineation of DUs for caribou across Canada and suggest practical approaches toward the inclusion of TK in the development of policies related to SARA.

Multidisciplinary research broadens the scope of biological inquiry and recognizes the significant contribution that multiple knowledge sources provide (Gavin et al. 2015). By exploring multiple ways of organizing knowledge our research was able to forge the basis for cross-cultural collaboration. For example, by investing in cooperation from the onset, our project produced results that have been acknowledged from different world views, thus our research outcomes may be more broadly accepted. As Walter Bayha pointed out, "The future of research in the north will include more and more cases of science confirming the history of aboriginal people and thus add to the overall knowledge that has existed since time immemorial." Likewise, as demonstrated by our research, TK also has the potential to inform and improve scientific methods, processes, and outcomes. Through collaboration and łeghágots'enete "learning together" our research outlines ways to respectfully draw upon indigenous knowledge and support relationships between people and wildlife. By working with local communities, combining methods from different disciplines, and establishing potential for transformative dialogue, we can generate new insights and assist managers in confronting the daunting conservation challenges of the future.

\section{Responses to this article can be read online at:} http://www.ecologyandsociety.org/issues/responses. $\mathrm{php} / 8284$

\section{Acknowledgments:}

We would like to express heartfelt gratitude to all the individuals who participated in the project and our community partners, the Rehdzo Got'tne (Renewable Resources Councils), who made this work possible: specifically we thank Roger Boniface, Sarena Kaskamin, Wilfred Jackson, Lawrence Manuel, Patricia Manuel, Frank Tselele, Harry Harris, Roger Odgaard, Ricky Andrew, David Menacho, Roderick Yallee, Valerie Yakeleya, Julie Lennie, Dion Lennie, William Horassi, Joe Bernard, David Etchinelle, Rocky Norwegian, Alfred Taniton, Leon Modeste, Morris Neyelle, Charlie Neyelle, Sideny Tutcho, Mitchell Naedzo, Wilbert Kochon, and Marie Kochon among many others. Special thanks go to the late Angus Shae, Norm Hodgson, and Doug Urquhart whose knowledge was profound and whose presence is notably missed. The research advisory group was crucial to the work and we are indebted to them: Michael Neyelle, Walter Bayha, Jimmy Dillon, Gordon Yakeleya, Frederick Andrew, Leon Andrew, Maurice Mendo, Michel Lafferty, Judy Lafferty, Richard Kochon, Hyacinthe Kochon, Gabe Kochon, Lucy Jackson, and Camilla Rabisca. The SRRB board and staff provided consistent encouragement as well as financial, logistical, and administrative support for this project. Particular thanks are owed to Catarina Owen, Lori Ann Lennie, Kristen Kodakin, and Joe Hanlon. We thank ENR staff Richard Popko, Stephanie 
Behrens, Heather Sayine-Crawford, Laurel McDonald, Keith Hickling, Ron Doctor, Leroy Andre, Mabel Tatchinron, James Hodson, and Jeff Walker who enabled this work. Máhsi cho to Morris Modeste for enlarging our understanding of Dene language, generous hospitality, and collecting samples. We thank all those who helped collect samples especially Jeffery Jackson, who single handedly submitted over 130 samples and Veronique Kochon, our youngest caribou scat collector - máhst! Terrence Mackeinzo, Cheyenne Menacho, and high school students from the Mackenzie Mountain School helped with lab work in Norman Wells. Thanks to the staff of Nahanni National Park Reserve and Saoyu-?ehdacho National Historic Site who collected and transported samples. Rick Farnell, Susan Kutz, and Anja Carlsson generously provided caribou samples from their research projects. Essential laboratory assistance was provided by colleagues at Trent University. We especially thank Marina Kerr, Jill Lalor, and Bridget Redquest. We are grateful for discussions with colleagues that contributed to this work including Iain Davidson-Hunt, Amy Flasko, Laura Hebert, Sam McFarlane, Pauline Priadka, Paul Galpern, and Sandra Marken. Jesse Tigner of Explor provided helicopter flight time. General funding for this research was provided by the SRRB, ENR, Cumulative Impact Monitoring Program, Environmental Studies Research Fund, Parks Canada, University of Manitoba, and an NSERC Strategic Grant held by MM and PW. JLP thanks Claire Polfus, Morgan Moffitt, Jonaki Bhattacharyya, and Joe Hanlon for reviewing early versions of the manuscript and the Wilburforce Foundation for support through the Wilburforce Fellowship in Conservation Science.

\section{LITERATURE CITED}

Abel, K. M. 2005. Drum songs: glimpses of Dene history. McGillQueen's University Press, Montréal, Québec, Canada.

Agar, M., and J. MacDonald. 1995. Focus groups and ethnography. Human Organization 54:78-86. http://dx.doi. org/10.17730/humo.54.1.x102372362631282

Alcorn, J. B. 1993. Indigenous peoples and conservation. Conservation Biology 7:424-426. http://dx.doi.org/10.1046/ j.1523-1739.1993.07020424.X

Andrews, T., G. MacKay, L. Andrew, W. Stephenson, A. Barker, C. Alix, and the Shúhtagot'ine Elders of Tulita. 2012a. Alpine ice patches and Shúhtagot'ine land use in the Mackenzie and Selwyn Mountains, Northwest Territories, Canada. Arctic 65:22-42.

Andrews, T. D., G. MacKay, and L. Andrew. $2012 b$. Archaeological investigations of alpine ice patches in the Selwyn Mountains, Northwest Territories, Canada. Arctic 65:1-21.

Arnold, M. L., and N. D. Fogarty. 2009. Reticulate evolution and marine organisms: the final frontier? International Journal of Molecular Sciences 10:3836-3860.

Atran, S. 1990. Cognitive foundations of natural history: towards an anthropology of science. Cambridge University Press, Cambridge, UK.

Ball, M. 2007. Conservation genetics of Canadian boreal caribou (Rangifer tarandus caribou). Dissertation. Trent University, Peterborough, Ontario, Canada.

Ball, M. C., L. Finnegan, M. Manseau, and P. Wilson. 2010. Integrating multiple analytical approaches to spatially delineate and characterize genetic population structure: an application to boreal caribou (Rangifer tarandus caribou) in central Canada. Conservation Genetics 11:2131-2143. http://dx.doi.org/10.1007/ s10592-010-0099-3

Banfield, A. W. F. 1961. A revision of the reindeer and caribou, genus Rangifer. Queen's Printer, Ottawa, Ontario, Canada.

Basso, K. 1996. Wisdom sits in places: landscape and language among the Western Apache. University of New Mexico Press, Albuquerque, New Mexico, USA.

Beaulieu, D. 2012. Dene traditional knowledge about caribou cycles in the Northwest Territories. Rangifer 32:59-67. http://dx. doi.org/10.7557/2.32.2.2252

Berkes, F. 2012. Sacred ecology. Third edition. Taylor and Francis, New York, New York, USA.

Berkes, F., J. Colding, and C. Folke, editors. 2003. Navigating social-ecological systems: building resilience for complexity and change. Cambridge University Press, Cambridge, UK. http://dx. doi.org/10.1017/cbo9780511541957

Berlin, B. 1973. Folk systematics in relation to biological classification and nomenclature. Annual Review of Ecology and Systematics 4:259-271. http://dx.doi.org/10.1146/annurev. es.04.110173.001355

Berman, M., and G. Kofinas. 2004. Hunting for models: grounded and rational choice approaches to analyzing climate effects on subsistence hunting in an Arctic community. Ecological Economics 49:31-46. http://dx.doi.org/10.1016/j.ecolecon.2003.12.005

Bernard, H. R. 2002. Research methods in anthropology: qualitative and quantitative approaches. AltaMira Press, Lanham, Maryland, USA.

Bishop, M. D., S. M. Kappes, J. W. Keele, R. T. Stone, S. L. F. Sunden, G. A. Hawkins, S. S. Toldo, R. Fries, M. D. Grosz, J. Y. Yoo, and C. W. Beattie. 1994. A genetic-linkage map for cattle. Genetics 136:619-639.

Bodin, Ö., and M. Tengö. 2012. Disentangling intangible socialecological systems. Global Environmental Change 22:430-439. http://dx.doi.org/10.1016/j.gloenvcha.2012.01.005

Boroditsky, L. 2011. How language shapes thought. Scientific American 304:62-65. http://dx.doi.org/10.1038/scientificamerican0211-62

Boulet, M., S. Couturier, S. D. Côté, R. D. Otto, and L. Bernatchez. 2007. Integrative use of spatial, genetic, and demographic analyses for investigating genetic connectivity between migratory, montane, and sedentary caribou herds. Molecular Ecology 16:4223-4240. http://dx.doi.org/10.1111/ j.1365-294X.2007.03476.X

Bowen, B. W. 1999. Preserving genes, species, or ecosystems? Healing the fractured foundations of conservation policy. Molecular Ecology 8:S5-S10. http://dx.doi.org/10.1046/ j.1365-294x.1999.00798.x

Brightman, R. A. 2002. Grateful prey: Rock Cree human-animal relationships. Canadian Plains Research Center, University of Regina, Regina, Saskatchewan, Canada.

Brook, R. K., S. J. Kutz, A. M. Veitch, R. A. Popko, B. T. Elkin, and G. Guthrie. 2009. Fostering community-based wildlife health 
monitoring and research in the Canadian north. EcoHealth 6:266-278. http://dx.doi.org/10.1007/s10393-009-0256-7

Brown, G. S., W. J. Rettie, R. J. Brooks, and F. F. Mallory. 2007. Predicting the impacts of forest management on woodland caribou habitat suitability in black spruce boreal forest. Forest Ecology and Management 245:137-147. http://dx.doi.org/10.1016/ j.forec0.2007.04.016

Chan, K. M. A., and S. A. Levin. 2005. Leaky prezygotic isolation and porous genomes: rapid introgression of maternally inherited DNA. Evolution 59:720-729. http://dx.doi.org/10.1111/j.0014-3820.2005. tb01748.x

Collins, S. L., S. R. Carpenter, S. M. Swinton, D. E. Orenstein, D. L. Childers, T. L. Gragson, N. B. Grimm, J. M. Grove, S. L. Harlan, J. P. Kaye, et al. 2011. An integrated conceptual framework for long-term social-ecological research. Frontiers in Ecology and the Environment 9:351-357. http://dx.doi. org/10.1890/100068

Colson, K. E., K. H. Mager, and K. J. Hundertmark. 2014. Reindeer introgression and the population genetics of caribou in southwestern Alaska. Journal of Heredity 105:585-596. http://dx. doi.org/10.1093/jhered/esu030

Committee on the Status of Endangered Wildlife in Canada (COSEWIC). 2011. Designatable units for caribou (Rangifer tarandus) in Canada. COSEWIC, Ottawa, Ontario, Canada.

Cornwall, A., and R. Jewkes. 1995. What is participatory research? Social Science \& Medicine 41:1667-1676.

Courtois, R., J. P. Ouellet, L. Breton, A. Gingras, and C. Dussault. 2007. Effects of forest disturbance on density, space use, and mortality of woodland caribou. Ecoscience 14:491-498. http://dx. doi.org/10.2980/1195-6860(2007)14[491:EOFDOD]2.0.CO;2

Crandall, K. A. 2009. A multifaceted approach to species conservation. Animal Conservation 12:105-106. http://dx.doi. org/10.1111/j.1469-1795.2009.00254.X

Crandall, K. A., O. R. P. Bininda-Emonds, G. M. Mace, and R. K. Wayne. 2000. Considering evolutionary processes in conservation biology. Trends in Ecology \& Evolution 15:290-295. http://dx.doi.org/10.1016/s0169-5347(00)01876-0

Cronin, M. A., M. D. MacNeil, and J. C. Patton. 2005. Variation in mitochondrial DNA and microsatellite DNA in caribou (Rangifer tarandus) in North America. Journal of Mammalogy 86:495-505. http://dx.doi.org/10.1644/1545-1542(2005)86[495:VIMDAM] 2.0.CO:2

Cruikshank, J. 1981. Legend and landscape: convergence of oral and scientific traditions in the Yukon Territory. Arctic Anthropology 18:67-93.

Davidson-Hunt, I. J. 2006. Adaptive learning networks: developing resource management knowledge through social learning forums. Human Ecology 34:593-614. http://dx.doi. org/10.1007/s10745-006-9009-1

Davidson-Hunt, I. J., P. Jack, E. Mandamin, and B. Wapioke. 2005. Iskatewizaagegan (Shoal Lake) plant knowledge: an Anishinaabe (Ojibway) ethnobotany of Northwestern Ontario.
Journal of Ethnobiology 25:189-227. http://dx.doi.org/10.2993/0278-0771 (2005)25[189:ISLPKA]2.0.CO;2

Davidson-Hunt, I. J., K. L. Turner, A. T. P. Mead, J. CabreraLopez, R. Bolton, C. J. Idrobo, I. Miretski, A. Morrison, and J. P. Robson. 2012. Biocultural design: a new conceptual framework for sustainable development in rural indigenous and local communities. Sapiens 5:33-45.

Deutscher, G. 2010. Through the language glass: how words colour your world. William Heinemann, London, UK.

Dyke, L. D. 2000. Climate of the Mackenzie River valley. Pages 21-30 in L. D. Dyke and G. R. Brooks, editors. The physical environment of the Mackenzie Valley, Northwest Territories: a base line for the assessment of environmental change. Geological Survey of Canada Bulletin 547. Natural Resources Canada, Ottawa, Ontario, Canada.

Earl, D. A., and B. M. vonHoldt. 2012. STRUCTURE HARVESTER: a website and program for visualizing STRUCTURE output and implementing the Evanno method. Conservation Genetics Resources 4:359-361. http://dx.doi. org/10.1007/s12686-011-9548-7

Eizaguirre, C., and M. Baltazar-Soares. 2014. Evolutionary conservation-evaluating the adaptive potential of species. Evolutionary Applications 7:963-967. http://dx.doi.org/10.1111/ eva. 12227

Environment Canada. 2012. Recovery strategy for the Woodland Caribou (Rangifer tarandus caribou), boreal population, in Canada. Species at Risk Act Recovery Strategy Series. Environment Canada. Ottawa, Ontario, Canada.

Evans, N. 2012. Anything can happen: the verb lexicon and interdisciplinary fieldwork. Pages 183-208 in N. Thieberger, editor. The Oxford handbook of linguistic fieldwork. Oxford University Press, New York, New York, USA. http://dx.doi. org/10.1093/oxfordhb/9780199571888.013.0009

Excoffier, L., and H. E. L. Lischer. 2010. Arlequin suite ver 3.5: a new series of programs to perform population genetics analyses under Linux and Windows. Molecular Ecology Resources 10:564-567. http://dx.doi.org/10.1111/j.1755-0998.2010.02847.x

Falush, D., M. Stephens, and J. K. Pritchard. 2003. Inference of population structure using multilocus genotype data: linked loci and correlated allele frequencies. Genetics 164:1567-1587.

Ferreira, M. P., and F. Gendron. 2011. Community-based participatory research with traditional and indigenous communities of the Americas: Historical context and future directions. The International Journal of Critical Pedagogy 3:153-168.

Fitzpatrick, B. M., M. E. Ryan, J. R. Johnson, J. Corush, and E. T. Carter. 2015. Hybridization and the species problem in conservation. Current Zoology 61:206-216. http://dx.doi. org/10.1093/czoolo/61.1.206

Flagstad, Ø., and K. H. Røed. 2003. Refugial origins of reindeer (Rangifer tarandus L.) inferred from mitochondrial DNA sequences. Evolution 57:658-670. http://dx.doi.org/10.1111/ j.0014-3820.2003.tb01557.x 
Ford, D. 2008. Report upon a survey of karst landforms around Norman Wells, Northwest Territories. Department of Environment and Natural Resources, Government of the Northwest Territories, Yellowknife, Northwest Territories, Canada.

Fraser, D. J., and L. Bernatchez. 2001. Adaptive evolutionary conservation: towards a unified concept for defining conservation units. Molecular Ecology 10:2741-2752.

Fraser, D. J., T. Coon, M. R. Prince, R. Dion, and L. Bernatchez. 2006. Integrating traditional and evolutionary knowledge in biodiversity conservation: a population level case study. Ecology and Society 11(2):4. [online] URL: http://www.ecologyandsociety. org/vol11/iss 2/art4/

Galpern, P., M. Manseau, P. Hettinga, P. Wilson, and K. Smith. 2012b. ALLELEMATCH: an R package for identifying unique multilocus genotypes where genotyping error and missing data may be present. Molecular Ecology Resources 12:771-778.

Galpern, P., M. Manseau, and P. Wilson. 2012a. Grains of connectivity: analysis at multiple spatial scales in landscape genetics. Molecular Ecology 21:3996-4009.

Gavin, M. C., J. McCarter, A. Mead, F. Berkes, J. R. Stepp, D. Peterson, and R. Tang. 2015. Defining biocultural approaches to conservation. Trends in Ecology \& Evolution 30:140-145. http:// dx.doi.org/10.1016/j.tree.2014.12.005

Glaser, B. G., and A. L. Strauss. 1967. The discovery of grounded theory: strategies for qualitative research. Transaction, New Brunswick, New Jersey, USA.

Good, J. M., S. Hird, N. Reid, J. R. Demboski, S. J. Steppan, T. R. Martin-Nims, and J. Sullivan. 2008. Ancient hybridization and mitochondrial capture between two species of chipmunks. Molecular Ecology 17:1313-1327. http://dx.doi.org/10.1111/ j.1365-294X.2007.03640.X

Gordon, B. 2003. Rangifer and man: an ancient relationship. Rangifer 23:15-28. http://dx.doi.org/10.7557/2.23.5.1651

Gordon, B. C. 2005. 8000 years of caribou and human seasonal migration in the Canadian Barrenlands. Rangifer 16:155-162. http://dx.doi.org/10.7557/2.25.4.1780

Gullickson, D. B., and M. Manseau. 2000. South Nahanni woodland caribou herd seasonal range use and demography. Parks Canada Agency, Gatineau, Québec, Canada.

Hale, K., M. Krauss, L. J. Watahomigie, A. Y. Yamamoto, C. Craig, L. M. Jeanne, and N. C. England. 1992. Endangered languages. Language 68:1-42. http://dx.doi.org/10.2307/416368

Hall, B. L. 1979. Knowledge as a commodity and participatory research. Prospects: Quarterly Review of Education 9:393-408. http://dx.doi.org/10.1007/bf02331493

Hall, T. A. 1999. BioEdit: a user-friendly biological sequence alignment editor and analysis program for Windows 95/98/NT. Nucleic Acids Symposium Series. Oxford University Press, Oxford, UK.

Hamilton, J. A., and J. M. Miller. 2016. Adaptive introgression as a resource for management and genetic conservation in a changing climate. Conservation Biology 30:33-41. http://dx.doi. org/10.1111/cobi.12574
Hardy, O. J., and X. Vekemans. 2002. SPAGeDi: a versatile computer program to analyse spatial genetic structure at the individual or population levels. Molecular Ecology Notes 2:618-620. http://dx.doi.org/10.1046/j.1471-8286.2002.00305.x

Harnum, B., J. Hanlon, T. Lim, J. Modeste, S. Deborah, and A. Spring. 2014. Best of both worlds: Sahtú gonęné t'áadets'enitǫ. (Depending on the land in the Sahtú region). The Pembina Institute and ?ehdzo Got'ı̨nę Gots'ę Nákedı (Sahtú Renewable Resources Board). Tulit'a, Northwest Territories, Canada.

Harrison, K. D. 2007. When languages die: the extinction of the world's languages and the erosion of human knowledge. Oxford University Press, New York, New York, USA. http://dx.doi. org/10.1093/acprof:oso/9780195181920.001.0001

Hebblewhite, M., C. White, and M. Musiani. 2010. Revisiting extinction in national parks: mountain caribou in Banff. Conservation Biology 24:341-344. http://dx.doi.org/10.1111/ j.1523-1739.2009.01343.X

Heginbottom, J. A. 2000. Permafrost distribution and ground ice in surficial materials. Pages 31-39 in L. D. Dyke and G. R. Brooks, editors. The physical environment of the Mackenzie Valley, Northwest Territories: a base line for the assessment of environmental change. Geological Survey of Canada Bulletin 547. Natural Resources Canada, Ottawa, Ontario, Canada.

Helm, J. N., L. Oestreich, and T. S. Carterette. 2000. The people of Denendeh: ethnohistory of the Indians of Canada's Northwest Territories. McGill-Queen's University Press, Montréal, Québec, Canada.

Hettinga, P. N., A. N. Arnason, M. Manseau, D. Cross, K. Whaley, and P. J. Wilson. 2012. Estimating size and trend of the North Interlake woodland caribou population using fecal-DNA and capture-recapture models. Journal of Wildlife Management 76:1153-1164. http://dx.doi.org/10.1002/jwmg. 380

Hey, J. 2001. Genes, categories and species: the evolutionary and cognitive causes of the species problem. Oxford University Press, New York, New York, USA.

Hey, J. 2006. On the failure of modern species concepts. Trends in Ecology \& Evolution 21:447-450. http://dx.doi.org/10.1016/j. tree.2006.05.011

Hird, S., and J. Sullivan. 2009. Assessment of gene flow across a hybrid zone in red-tailed chipmunks (Tamias ruficaudus). Molecular Ecology 18:3097-3109. http://dx.doi.org/10.1111/ j.1365-294X.2009.04196.X

Hunn, E. 2006. Meeting of minds: how do we share our appreciation of traditional environmental knowledge? Journal of the Royal Anthropological Institute 12:S143-S160.

Ingold, T. 2000. The perception of the environment: essays on livelihood, dwelling and skill. Routledge, London, UK. http://dx. doi.org/10.4324/9780203466025

Ingold, T. 2011. Being alive: essays on movement, knowledge and description. Taylor and Francis, Abingdon, UK.

Jakobsson, M., and N. A. Rosenberg. 2007. CLUMPP: a cluster matching and permutation program for dealing with label switching and multimodality in analysis of population structure. Bioinformatics 23:1801-1806. http://dx.doi.org/10.1093/bioinformatics/ $\underline{\text { btm } 233}$ 
Johnson, C. J., L. P. W. Ehlers, and D. R. Seip. 2015. Witnessing extinction - cumulative impacts across landscapes and the future loss of an evolutionarily significant unit of woodland caribou in Canada. Biological Conservation 186:176-186. http://dx.doi. org/10.1016/j.biocon.2015.03.012

Kalinowski, S. T. 2005. HP-Rare 1.0: a computer program for performing rarefaction on measures of allelic richness. Molecular Ecology Notes 5:187-189. http://dx.doi.org/10.1111/

j.1471-8286.2004.00845.x

Klütsch, C. F. C., M. Manseau, V. Trim, J. L. Polfus, and P. J. Wilson. 2016. The eastern migratory caribou: the role of genetic introgression in ecotype evolution. Royal Society Open Science 3:150469. http://dx.doi.org/10.1098/rsos. 150469

Klütsch, C. F. C., M. Manseau, and P. J. Wilson. 2012. Phylogeographical analysis of mtDNA data indicates postglacial expansion from multiple glacial refugia in woodland caribou (Rangifer tarandus caribou). PLoS ONE 7:e52661. http://dx.doi. org/10.1371/journal.pone.0052661

Kokelj, S. A. 2001. Hydrologic overview of the Gwich'in and Sahtu settlement areas. Water Resources Division, Indian and Northern Affairs Canada, Yellowknife, Northwest Territories, Canada.

Krauss, M. E., and V. K. Golla. 1981. North Athapaskan languages. Pages 469-480 in J. Helm, editor. Handbook of North American Indians. Vol. 6, Subarctic. Smithsonian Institution, Washington, D.C., USA.

Lakoff, G. 1990. Women, fire, and dangerous things: what categories reveal about the mind. The University of Chicago Press, Chicago, Illinois, USA.

Legat, A. 2012. Walking the land, feeding the fire: knowledge and stewardship among the Titicho Dene. University of Arizona Press, Tucson, Arizona, USA.

Letts, B., T. L. Fulton, M. Stiller, T. D. Andrews, G. MacKay, R. Popko, and B. Shapiro. 2012. Ancient DNA reveals genetic continuity in mountain woodland caribou of the Mackenzie and Selwyn Mountains, Northwest Territories, Canada. Arctic 65:80-94. http://dx.doi.org/10.14430/arctic4186

Liu, J., T. Dietz, S. R. Carpenter, M. Alberti, C. Folke, E. Moran, A. N. Pell, P. Deadman, T. Kratz, J. Lubchenco, et al. 2007. Complexity of coupled human and natural systems. Science 317:1513-1516. http://dx.doi.org/10.1126/science.1144004

Loh, J., and D. Harmon. 2014. Biocultural diversity: threatened species, endangered languages. WWF Netherlands, Zeist, The Netherlands.

Mace, G. M. 2004. The role of taxonomy in species conservation. Philosophical Transactions of the Royal Society of London Series B-Biological Sciences 359:711-719. http://dx.doi.org/10.1098/ rstb.2003.1454

Mager, K. H. 2012. "I'd be foolish to tell you they were caribou": local knowledge of historical interactions between reindeer and caribou in Barrow, Alaska. Arctic Anthropology 49:162-181. http://dx.doi.org/10.1353/arc.2012.0023

Mager, K. H., K. E. Colson, and K. J. Hundertmark. 2013. High genetic connectivity and introgression from domestic reindeer characterize northern Alaska caribou herds. Conservation Genetics 14:1111-1123 http://dx.doi.org/10.1007/s10592-013-0499-2

Mallet, J. 2005. Hybridization as an invasion of the genome. Trends in Eecology \& Evolution 20:229-237.

Mallet, J. 2008. Hybridization, ecological races and the nature of species: empirical evidence for the ease of speciation. Philosophical Transactions of the Royal Society of London B: Biological Sciences 363:2971-2986. http://dx.doi.org/10.1098/ rstb.2008.0081

Markman, E. M., and J. E. Hutchinson. 1984. Children's sensitivity to constraints on word meaning: taxonomic versus thematic relations. Cognitive Psychology 16:1-27. http://dx.doi. org/10.1016/0010-0285(84)90002-1

McDevitt, A. D., S. Mariani, M. Hebblewhite, N. J. Decesare, L. Morgantini, D. Seip, B. V. Weckworth, and M. Musiani. 2009. Survival in the Rockies of an endangered hybrid swarm from diverged caribou (Rangifer tarandus) lineages. Molecular Ecology 18:665-679. http://dx.doi.org/10.1111/j.1365-294X.2008.04050. $\underline{x}$

McFarlane, K., A. Gunn, and C. Strobeck, editors. 2009. Proceedings from the caribou genetics and relationship workshop. Department of Natural Resources and Environment Government of the Northwest Territories, Edmonton, Alberta, Canada.

McMillan, R., and B. Parlee. 2013. Dene hunting organization in Fort Good Hope, Northwest Territories: "ways we help each other and share what we can." Arctic 66:435-447. http://dx.doi. org/10.14430/arctic4330

Mee, J. A., L. Bernatchez, J. D. Reist, S. M. Rogers, and E. B. Taylor. 2015. Identifying designatable units for intraspecific conservation prioritization: a hierarchical approach applied to the lake whitefish species complex (Coregonus spp.). Evolutionary Applications 8:423-441. http://dx.doi.org/10.1111/eva.12247

Miller, A. M., and I. Davidson-Hunt. 2013. Agency and resilience: teachings of Pikangikum First Nation elders, northwestern Ontario. Ecology and Society 18(3):9. http://dx.doi.org/10.5751/ es-05665-180309

Moir, J. S. 1998. Petitot, Émile. Dictionary of Canadian Biography Vol. 14(1911-1920). University of Toronto, Toronto, Ontario and Université Laval, Québec City, Québec, Canada. [online] URL: http://www.biographi.ca/en/bio/petitot emile 14E.html

Morgan, D. L. 1996. Focus groups. Annual Review of Sociology 22:129-152. http://dx.doi.org/10.1146/annurev.soc.22.1.129

Morgan, S., and K. Anderson. 2013. State of knowledge: watersheds of concern to Fort Good Hope, NWT. A review of available research for the central Mackenzie-Ramparts and Hare Indian watersheds. A component of the vulnerability assessment for Fort Good Hope. Pembina Institute. Yellowknife, Northwest Territories, Canada.

Moritz, C. 2002. Strategies to protect biological diversity and the evolutionary processes that sustain it. Systematic Biology 51:238-254. http://dx.doi.org/10.1080/10635150252899752 
Nagy, J. A., D. L. Johnson, N. C. Larter, M. W. Campbell, A. E. Derocher, A. Kelly, M. Dumond, D. Allaire, and B. Croft. 2011. Subpopulation structure of caribou (Rangifer tarandus L.) in arctic and subarctic Canada. Ecological Applications 21:2334-2348. http://dx.doi.org/10.1890/10-1410.1

Nazarea, V. D. 2006. Local knowledge and memory in biodiversity conservation. Annual Review of Anthropology 35:317-335. http://dx.doi.org/10.1146/annurev.anthro.35.081705.123252

Newmaster, S. G., S. Ragupathy, F. I. Rebecca, and C. B. Nirmala. 2006. Mechanisms of ethnobiological classification. Ethnobotany 18:4-26.

Newmaster, S. G., R. Subramanyam, N. C. Balasubramaniyam, and R. F. Ivanoff. 2007. The multi-mechanistic taxonomy of the Irulas in Tamil Nadu, south India. Journal of Ethnobiology 27:233-255. http://dx.doi.org/10.2993/0278-0771(2007)27[233:TMTOTI] 2.0.CO;2

Northwest Territories Bureau of Statistics. 2014. Language: Language by community. Excel spreadsheet. NWT Bureau of Statistics, Yellowknife, Northwest Territories, Canada. online URL: http://www.statsnwt.ca/language/

O'Brien, D., M. Manseau, A. Fall, and M. J. Fortin. 2006. Testing the importance of spatial configuration of winter habitat for woodland caribou: an application of graph theory. Biological Conservation 130:70-83. http://dx.doi.org/10.1016/j.biocon.2005.12.014

O’Flaherty, R. M., I. J. Davidson-Hunt, and M. Manseau. 2008. Indigenous knowledge and values in planning for sustainable forestry: Pikangikum First Nation and the Whitefeather Forest Initiative. Ecology and Society 13(1):6. http://www.ecologyandsociety. org/vol13/iss1/art6/

Padial, J. M., A. Miralles, I. De la Riva, and M. Vences. 2010. Review: the integrative future of taxonomy. Frontiers in Zoology 7:1-14. http://dx.doi.org/10.1186/1742-9994-7-16

Peakall, R., and P. E. Smouse. 2006. GENALEX 6: genetic analysis in Excel. Population genetic software for teaching and research. Molecular Ecology Notes 6:288-295. http://dx.doi. org/10.1111/j.1471-8286.2005.01155.X

Peakall, R., and P. E. Smouse. 2012. GenAlEx 6.5: genetic analysis in Excel. Population genetic software for teaching and research an update. Bioinformatics 28:2537-2539. http://dx.doi.org/10.1093/ $\underline{\text { bioinformatics/bts } 460}$

Petitot, É. F. 1893. Exploration of the Great Bear Lake region (End of Quinze ans sous le cercle polaire). Téqui, Bookseller and Publisher, Paris, France.

Polfus, J. L., M. Hebblewhite, and K. Heinemeyer. 2011. Identifying indirect habitat loss and avoidance of human infrastructure by northern mountain woodland caribou. Biological Conservation 144:2637-2646. http://dx.doi.org/10.1016/ j.biocon.2011.07.023

Polfus, J. L., K. Heinemeyer, M. Hebblewhite, and Taku River Tlingit First Nation. 2014. Comparing traditional ecological knowledge and western science woodland caribou habitat models. Journal of Wildlife Management 78:112-121. http://dx.doi. org/10.1002/jwmg.643
Pond, B. A., G. S. Brown, K. S. Wilson, and J. A. Schaefer. 2016. Drawing lines: spatial behaviours reveal two ecotypes of woodland caribou. Biological Conservation 194:139-148. http:// dx.doi.org/10.1016/j.biocon.2015.12.005

Pritchard, J. K., M. Stephens, and P. Donnelly. 2000. Inference of population structure using multilocus genotype data. Genetics 155:945-959.

Puckett, E. E., P. D. Etter, E. A. Johnson, and L. S. Eggert. 2015. Phylogeographic analyses of American black bears (Ursus americanus) suggest four glacial refugia and complex patterns of post-glacial admixture. Molecular Biology and Evolution 32 (9):2338-2350. http://dx.doi.org/10.1093/molbev/msv114

Ragupathy, S., S. G. Newmaster, M. Murugesan, and V. Balasubramaniam. 2009. DNA barcoding discriminates a new cryptic grass species revealed in an ethnobotany study by the hill tribes of the Western Ghats in southern India. Molecular Ecology Resources 9:164-171. http://dx.doi.org/10.1111/j.1755-0998.2009.02641. $\underline{x}$

Rhymer, J. M., and D. Simberloff. 1996. Extinction by hybridization and introgression. Annual Review of Ecology and Systematics 27:83-109. http://dx.doi.org/10.1146/annurev.ecolsys.27.1.83

Rice, K. 1989. A grammar of Slave. Mouton de Gruyter, Berlin, Germany. http://dx.doi.org/10.1515/9783110861822

Røed, K. H., G. Bjørnstad, Ø. Flagstad, H. Haanes, A. K. Hufthammer, P. Jordhøy, and J. Rosvold. 2014. Ancient DNA reveals prehistoric habitat fragmentation and recent domestic introgression into native wild reindeer. Conservation Genetics 15:1137-1149. http://dx.doi.org/10.1007/s10592-014-0606-Z

Rosenberg, N. A. 2004. DISTRUCT: a program for the graphical display of population structure. Molecular Ecology Notes 4:137-138. http://dx.doi.org/10.1046/j.1471-8286.2003.00566.x

Rousset, F. 2008. GENEPOP'007: a complete re-implementation of the GENEPOP software for Windows and Linux. Molecular Ecology Resources 8:103-106. http://dx.doi.org/10.1111/ j.1471-8286.2007.01931.x

Sangris, F. 2012. Renewing our traditional laws through joint ekwo (caribou) management. Rangifer 32:75-80. http://dx.doi. org/10.7557/2.32.2.2254

Scott, C. 2011. Science for the west, myth for the rest? The case of James Bay Cree knowledge construction. Pages 175-197 in S. Harding, editor. The postcolonial science and technology studies reader. Duke University Press, Durham, North Carolina, USA.

Species at Risk Committee. 2012. Species status report for boreal caribou (Rangifer tarandus caribou) in the Northwest Territories. Species at Risk Committee, Yellowknife, Northwest Territories, Canada.

Statistics Canada. 2012. Region 2, Northwest Territories (Code 6102) and Northwest Territories (Code 61). Census Profile. 2011 Census. Statistics Canada Catalogue no. 98-316-XWE. Statistics Canada, Ottawa, Ontario, Canada.

Stevenson, M. G. 1998. Traditional knowledge and environmental management: from commodity to process. Sustainable Forest 
Management Network working paper 1998-14. University of Alberta. Edmonton, Alberta, Canada.

Stiebens, V. A., S. E. Merino, C. Roder, F. J. J. Chain, P. L. M. Lee, and C. Eizaguirre. 2013. Living on the edge: how philopatry maintains adaptive potential. Proceedings of the Royal Society of London B: Biological Sciences 280:20130305. http://dx.doi. org/10.1098/rspb.2013.0305

Stronen, A. V., E. L. Navid, M. S. Quinn, P. C. Paquet, H. M. Bryan, and C. T. Darimont. 2014. Population genetic structure of gray wolves (Canis lupus) in a marine archipelago suggests island-mainland differentiation consistent with dietary niche. BMC Ecology 14:11. http://dx.doi.org/10.1186/1472-6785-14-11

Stuart-Smith, A. K., C. J. A. Bradshaw, S. Boutin, D. M. Hebert, and A. B. Rippin. 1997. Woodland caribou relative to landscape patterns in northeastern Alberta. Journal of Wildlife Management 61:622-633. http://dx.doi.org/10.2307/3802170

Twomey, E., J. S. Vestergaard, and K. Summers. 2014. Reproductive isolation related to mimetic divergence in the poison frog Ranitomeya imitator. Nature Communications 5:1-8. http:// dx.doi.org/10.1038/ncomms5749

Vors, L. S., and M. S. Boyce. 2009. Global declines of caribou and reindeer. Global Change Biology 15:2626-2633. http://dx.doi. org/10.1111/j.1365-2486.2009.01974.X

Weckworth, B. V., M. Musiani, A. D. McDevitt, M. Hebblewhite, and S. Mariani. 2012. Reconstruction of caribou evolutionary history in western North America and its implications for conservation. Molecular Ecology 21:3610-3624. http://dx.doi. org/10.1111/j.1365-294X.2012.05621.X

Wilson, G. A., C. Strobeck, L. Wu, and J. W. Coffin. 1997. Characterization of microsatellite loci in caribou Rangifer tarandus, and their use in other artiodactyls. Molecular Ecology 6:697-699. http://dx.doi.org/10.1046/j.1365-294X.1997.00237.x

Wood, D. A., R. N. Fisher, and A. G. Vandergast. 2014. Fuzzy boundaries: color and gene flow patterns among parapatric lineages of the western shovel-nosed snake and taxonomic implication. PLoS ONE 9:e97494. http://dx.doi.org/10.1371/ journal.pone.0097494

Yannic, G., L. Pellissier, J. Ortego, N. Lecomte, S. Couturier, C. Cuyler, C. Dussault, K. J. Hundertmark, R. J. Irvine, D. A. Jenkins, L. Kolpashikov, K. Mager, M. Musiani, K. L. Parker, K. H. Røed, T. Sipko, S. G. Pórisson, B. V. Weckworth, A. Guisan, L. Bernatchez, and S. D. Côté. 2014. Genetic diversity in caribou linked to past and future climate change. Nature Climate Change 4:132-137. http://dx.doi.org/10.1038/nclimate2074 
Polfus, J. L., M. Manseau, D. Simmons, M. Neyelle, W. Bayha, F. Andrew, L. Andrew, C. F. C. Klütsch, K. Rice, and P. Wilson. 2016. Łeghágots'enetę (learning together): the importance of indigenous perspectives in the identification of biological variation. Ecology and Society 21:(2)18.

Appendix 1. Community-collaborative research background.

In northern Canada, landscapes, people and wildlife are inextricably and compellingly intertwined. Federal control over wildlife and the exclusion of indigenous people in wildlife management and decision-making for much of the $19^{\text {th }}$ century has generated environmental, jurisdictional, and political conflicts revolving around natural resources (Sandlos 2011). For many years science-based wildlife conservation approaches often had negative impacts on the traditional harvesting practices of indigenous peoples. For example, concerns about declining populations led to legislative controls by the federal government in the early 1900 s, prohibiting (and in some cases criminalizing) subsistence hunting of caribou and other large mammals and birds by Dene and Inuit hunters in the Northwest Territories (Sandlos 2011). Understanding the historical context of unequal power relations is an important part of developing new approaches to environmental research (Fletcher 2003, Nadasdy 2005, McGregor et al. 2010, Tobias et al. 2013).

In the 1970 s researchers working in the north began to acknowledge the importance of indigenous people's knowledge and priorities in natural resource research (Cruikshank 1981). However, early traditional knowledge (TK) research focused mostly on collecting objective and quantifiable information that could be packaged and accessed within scientific frameworks (Stevenson 1998). This led to substantial misrepresentation and the appropriation of knowledge (Nadasdy 2005, Castleden et al. 2012). A more recent shift in the orientation of research advocates for collaborative processes that serve indigenous interests, provide ownership and control of research outcomes, and include local people in decision-making processes (Hall 1979, 
Simpson 1999, Smith 1999, Simpson and Driben 2000). For example, community-based participatory research frameworks emerged in response to disrespectful and exclusionary approaches that concentrated research on people rather than with people (Simpson and Driben 2000, Fletcher 2003)

Participatory research (also including community-engaged, community-participatory, community-based, collaborative, cooperative; Ferreira and Gendron 2011) is intended to include people as active participants in all phases of the research process to "facilitate a more accurate and authentic analysis of social reality" (Hall 1979) and have been adapted in the fields of education (Hall 2005), public health (Christopher et al. 2011, Ferreira and Gendron 2011, Tobias et al. 2013), social science (Fletcher 2003), resource management (McKinley et al. 2012), and linguistics (Czaykowska-Higgins 2009) among others. The principles of participatory research include fostering a co-learning environment, answering relevant community-driven questions, focusing on co-capacity building and sustainable solutions, sharing decision-making responsibilities, and above all reflecting critically on the roles and power relations of those involved in the research process (Cornwall and Jewkes 1995, O'Fallon and Dearry 2002, Davidson-Hunt and O'Flaherty 2007)

In alignment with the principals of participatory research we brought together an interdisciplinary team of research partners and co-authors to build a solid foundation across diverse fields. Our research process was iterative and built on information and questions developed and refined over time. Significant knowledge exchange and łeghágots'enetę "learning together" between the co-authors and research partners occurred as ideas for the project were developed, at focus group meetings, during the selection of the field sampling sites, while 
collecting samples, and on the land during day trips, hunting trips and overnight trips to cabins. The distinct disciplinary backgrounds of team members, who spoke different first languages, necessitated significant dialogue to come to common understanding for a project.

The commitment, interest and openness of community research partners in the Sahtú region was crucial to the collaborative research process. Michael Neyelle, Walter Bayha, Frederick Andrew, and Leon Andrew are all native Dene language speakers and have significant TK experience and knowledge from their personal experiences and their parents and zehtséokə "grandparents". They have worked in collaboration with the Pehdzo Got'ı̨nę Gots'ę Náked1 (Sahtú Renewable Resources Board; SRRB) and other non-Dene researchers on various research projects over the years. Their interest in this research project, commitment to helping support the research, guidance on TK practices, and help with interpretation of the language, and their leadership positions within the communities allowed for new knowledge to be created and a common understanding to be reached. A focus on language during the research process was a means for Dene and non-Dene speakers to explore knowledge and understanding of the environment in more depth. For example, TK holders were able to unearth older knowledge that is not used every day. Non-Dene partners were able to explore the ways in which the words we use and the ideas we express influence the collaborative environment.

The project also included extended place-based research by non-Dene partners (Jean Polfus and Deborah Simmons live and work in the community of Tulit'a) that allowed for opportunities to participate in activities on-the-land and in the communities (thus learning was not restricted to research activities/agendas). Jean Polfus also traveled throughout the communities in the Sahtú to provide support for the Pehdzo Got'l̨nę (Renewable Resources 
Councils), collect caribou fecal samples with community members, participate in hunting activities, meet with students at local schools and Aurora Colleges and coordinate sampling efforts. The understanding required to respond appropriately to cultural cues and respectfully engage in łeghágots'enetę "learning together" is on-going, intangible and personal (for all research partners and co-authors) - but this exploration provides the necessary foundation needed to produce truly collaborative research.

Over time relationships were fostered that provided space for non-Dene researchers to learn important lessons regarding hunting traditions, on-the-land safety, and Dene rekwę rezah "caribou laws" required to demonstrate respect for the land and wildlife. Likewise, community members were also able to benefit from the collaborative relationship through increased contact with "outsider knowledge" (Caine et al. 2007), including expertise in wildlife biology, population genetics and linguistics, the chance to be involved in long-term natural resource management research and planning, and access to other resources that the non-Dene researchers could more easily acquire. The union of knowledge traditions can only be achieved though shared experiences, considerable time, and strong local and regional governance (McGregor et al. 2010). A large amount of knowledge was gained over time and cannot be readily summarized in a manuscript. The research process was organic and agreement on the interpretation of the results was gradual, forcing everyone to explore their own knowledge in depth, and in some cases leading to new questions and additional analysis.

Meeting the demands of academic requirements, funding agencies, and indigenous communities in the same process is fundamentally challenging and levels of participation, control and ownership of the research process and products often vary based on the complex 
constraints on each project (Cornwall and Jewkes 1995, Simpson and Driben 2000, Tondu et al. 2014). Our research benefitted considerably from the partnership with the SRRB. The board is a land-claim organization responsible for managing renewable resources. The SRRB's contributions to this project allowed our research to be firmly grounded in the communities needs and questions from the onset of the research because the project was built on pastexperiences and related work. The SRRB also facilitated ongoing communication with the public and local research partners by developing connections between various research agendas and other co-occurring projects. The opportunity for long-term planning and stability in the research process (implemented through connections with multiple community-driven projects and long term institutional research strategies and programs) is an important contribution of collaborative interdisciplinary research and the SRRB's involvement was essential to the success of the long term collaborative project. Thus, we were able to produce research contributions that were deeper and more robust than could have been achieved by a single, stand-alone academic research project. 


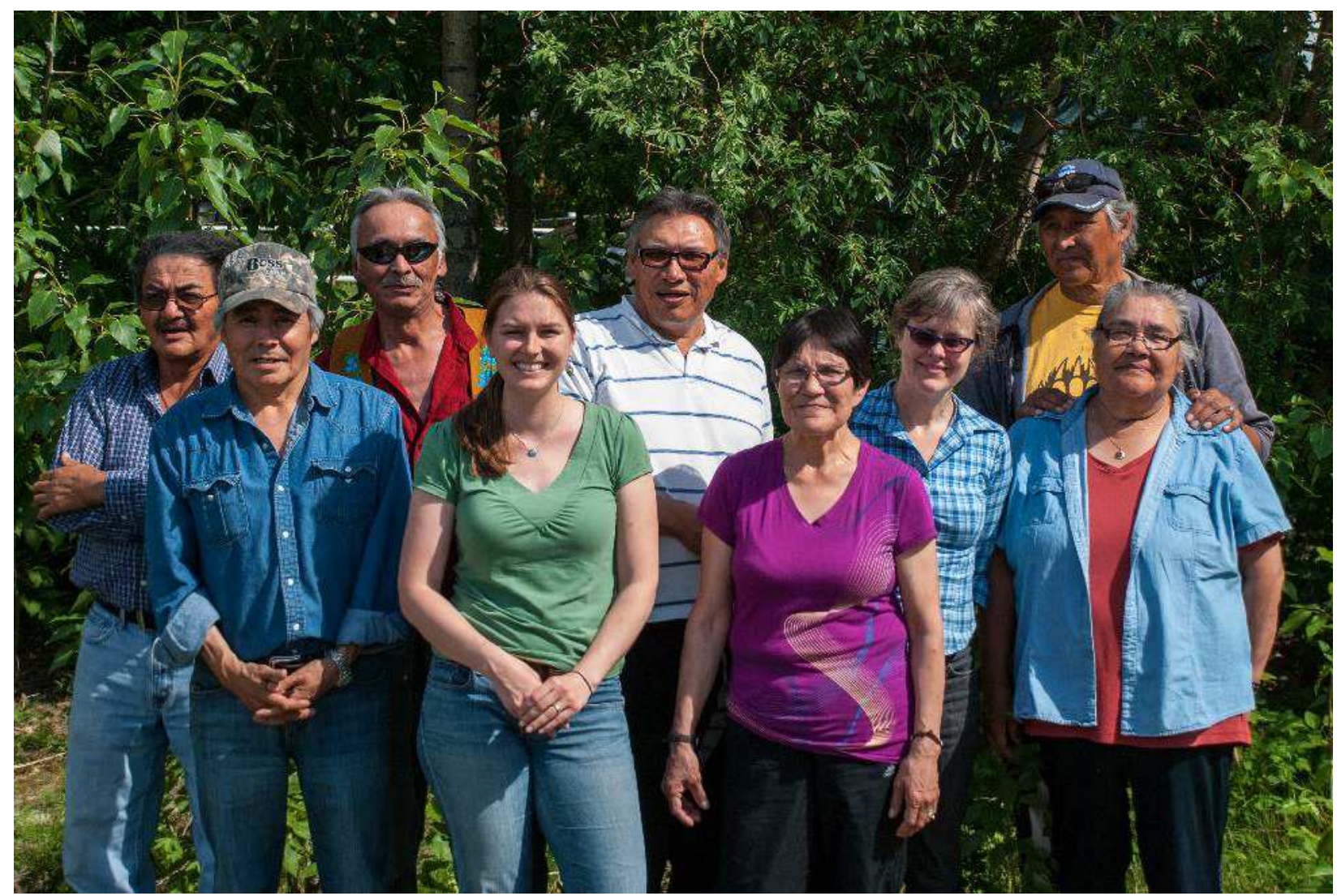

Figure A1.1. We discussed traditional knowledge themes, language, and genetic data with a local group of experts (advisory group, including co-authors) in two separate 3-day meetings to clarify and develop important concepts and themes related to caribou populations in the Sahtú region and Nahanni National Park Reserve of the Northwest Territories, Canada. Advisory group members June 2014 in Tulit'a, Northwest Territories: Gordon Yakeleya, Frederick Andrew, Michael Neyelle, Jean Polfus, Walter Bayha, Camilla Rabisca, Deborah Simmons, Michel Lafferty, and Judy Lafferty. 


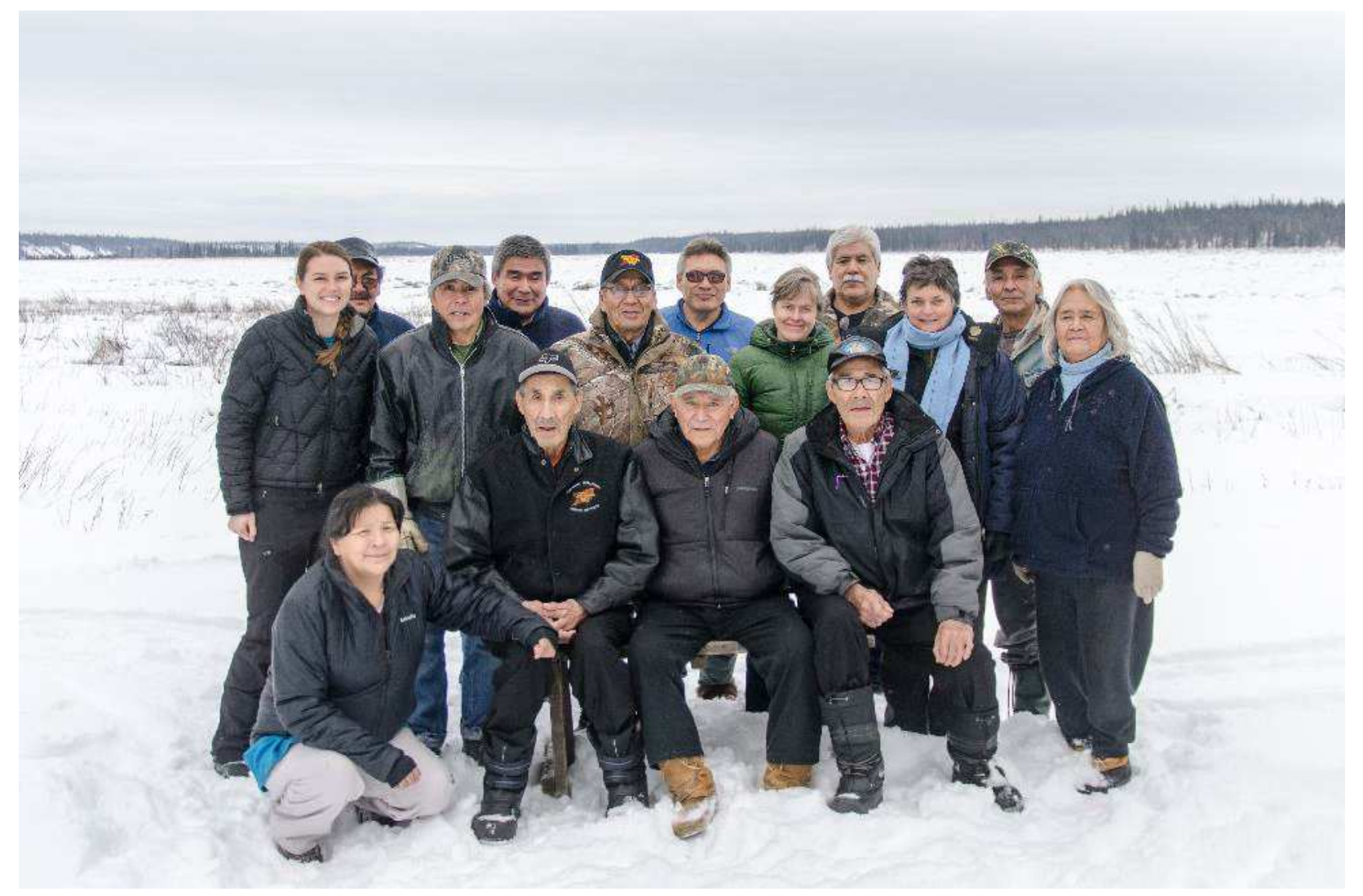

Figure A1.2. Advisory group members February 2015 at Deochah (Bennett Field), Northwest Territories: Back two rows - Jean Polfus, Gordon Yakeleya, Frederick Andrew, Richard Kochon, Jimmy Dillon, Walter Bayha, Deborah Simmons, Leon Andrew, Nicole Beaudry (ethnomusicologist), Michael Neyelle, and Lucy Jackson. Front row - Corrine Andrew (cook), Gabe Kochon, Maurice Mendo, and Hyacinth Kochon. 


\section{LITERATURE CITED}

Caine, K. J., M. J. Salomons, and D. Simmons. 2007. Partnerships for social change in the Canadian north: revisiting the insider-outsider dialectic. Development and Change $38: 447-471$.

Castleden, H., V. S. Morgan, and C. Lamb. 2012. "I spent the first year drinking tea": Exploring Canadian university researchers' perspectives on community-based participatory research involving Indigenous peoples. The Canadian Geographer/Le Géographe canadien 56:160-179.

Christopher, S., R. Saha, P. Lachapelle, D. Jennings, Y. Colclough, C. Cooper, C. Cummins, M. J. Eggers, K. FourStar, and K. Harris. 2011. Applying indigenous community-based participatory research principles to partnership development in health disparities research. Family \& community health 34:246-255.

Cornwall, A., and R. Jewkes. 1995. What is participatory research? Social science \& medicine 41:1667-1676.

Cruikshank, J. 1981. Legend and landscape: Convergence of oral and scientific traditions in the Yukon Territory. Arctic Anthropology 18:67-93.

Czaykowska-Higgins, E. 2009. Research models, community engagement, and linguistic fieldwork: Reflections on working within Canadian indigenous communities. Language documentation \& conservation 3:15-50.

Davidson-Hunt, I. J., and R. M. O'Flaherty. 2007. Researchers, indigenous peoples, and placebased learning communities. Society and Natural Resources 20:291-305.

Ferreira, M. P., and F. Gendron. 2011. Community-based participatory research with traditional and indigenous communities of the Americas: Historical context and future directions. The International Journal of Critical Pedagogy 3:153-168.

Fletcher, C. 2003. Community-based participatory research relationships with Aboriginal communities in Canada: an overview of context and process. Pimatisiwin: A Journal of Aboriginal \& Indigenous Community Health 1:27-62.

Hall, B. L. 1979. Knowledge as a commodity and participatory research. Prospects: Quarterly Review of education 9:393-408. 
Hall, B. L. 2005. In from the Cold? Reflections on Participatory Research from 1970-2005. Convergence 38:5-24.

McGregor, D., W. Bayha, and D. Simmons. 2010. Our responsibility to keep the land alive: voices of northern indigenous researchers. Pimatisiwin: A Journal of Aboriginal and Indigenous Community Health 8:101-123.

McKinley, D. C., R. D. Briggs, and A. M. Bartuska. 2012. When peer-reviewed publications are not enough! Delivering science for natural resource management. Forest Policy and Economics 21:1-11.

Nadasdy, P. 2005. The anti-politics of TEK: the institutionalization of co-management discourse and practice. Anthropologica:215-232.

O'Fallon, L. R., and A. Dearry. 2002. Community-based participatory research as a tool to advance environmental health sciences. Environmental health perspectives 110:155-159.

Sandlos, J. 2011. Hunters at the margin: Native people and wildlife conservation in the Northwest Territories. UBC Press, Vancouver, British Columbia, Canada.

Simpson, L. R. 1999. The construction of traditional ecological knowledge: issues, implications and insights. $\mathrm{PhD}$, University of Manitoba, Winnipeg, Manitoba, Canada.

Simpson, L. R., and P. Driben. 2000. From expert to acolyte: learning to understand the environment from an Anishinaabe point of view. American Indian culture and research journal 24:1-19.

Smith, L. T. 1999. Decolonizing methodologies: Research and indigenous peoples. Zed Books Ltd, London, UK.

Stevenson, M. G. 1998. Traditional Knowledge and environmental management: from commodity to process. Sustainable Forest Management Network working paper 1998-14. University of Alberta. Edmonton, Alberta, Canada.

Tobias, J. K., C. A. Richmond, and I. Luginaah. 2013. Community-based participatory research (CBPR) with indigenous communities: Producing respectful and reciprocal research. Journal of Empirical Research on Human Research Ethics: An International Journal 8:129-140. 
Tondu, J. M. E., A. M. Balasubramaniam, L. Chavarie, N. Gantner, J. A. Knopp, J. F. Provencher, P. B. Y. Wong, and D. Simmons. 2014. Working with northern communities to build collaborative research partnerships: perspectives from early career researchers. Arctic 67:419-429. 
Polfus, J. L., M. Manseau, D. Simmons, M. Neyelle, W. Bayha, F. Andrew, L. Andrew, C. F. C. Klütsch, K. Rice, and P. Wilson. 2016. Leghágots'enetę (learning together): the importance of indigenous perspectives in the identification of biological variation. Ecology and Society 21(2):18

Appendix 2. Population genetic summary statistics for caribou genetic samples collected in the Sahtú region and Nahanni National Park Reserve of the Northwest Territories, Canada from 2012 to 2014.

Erratum: Appendix 2 was updated on 16 May 2016.

Table A2.1. Summary of genetic diversity estimates for each microsatellite loci including allelic size range in base pairs, number of alleles $\left(\mathrm{N}_{\mathrm{A}}\right)$, observed $\left(\mathrm{H}_{\mathrm{O}}\right)$ and expected $\left(\mathrm{H}_{\mathrm{E}}\right)$ heterozygosity, FIs estimates and standard errors (SE) for caribou genetic data from the Northwest Territories, Canada. The original references for each loci are provided.

\begin{tabular}{lllllllll}
\hline $\begin{array}{l}\text { Microsatellite } \\
\text { Locus }\end{array}$ & $\begin{array}{l}\text { Allelic } \\
\text { Range }\end{array}$ & $\mathrm{N}_{\mathrm{A}}$ & $\mathrm{H}_{\mathrm{O}}$ & $\mathrm{SE}$ & $\mathrm{H}_{\mathrm{E}}$ & $\mathrm{SE}$ & $\mathrm{F}_{\mathrm{IS}}$ & Source \\
\hline BM848 & $356-386$ & 16 & 0.819 & 0.0234 & 0.864 & 0.0150 & 0.053 & Bishop et al. 1994 \\
BM888 & $162-260$ & 51 & 0.882 & 0.0041 & 0.865 & 0.0071 & -0.019 & Bishop et al. 1994 \\
Map2C & $89-115$ & 16 & 0.824 & 0.0113 & 0.850 & 0.0232 & 0.030 & Moore et al. 1992 \\
RT5 & $88-116$ & 15 & 0.768 & 0.0283 & 0.816 & 0.0373 & 0.058 & $\begin{array}{l}\text { McLoughlin et al. 2004 } \\
\text {, }\end{array}$ \\
& & & & & & & & Wilson et al. 1997 \\
RT6 & $88-112$ & 14 & 0.837 & 0.0122 & 0.833 & 0.0245 & -0.005 & Wilson et al. 1997 \\
RT7 & $210-232$ & 12 & 0.746 & 0.0242 & 0.772 & 0.0109 & 0.033 & Wilson et al. 1997 \\
RT9 & $100-128$ & 15 & 0.840 & 0.0257 & 0.859 & 0.0077 & 0.022 & Wilson et al. 1997 \\
RT24 & $205-227$ & 24 & 0.780 & 0.0497 & 0.786 & 0.0707 & 0.008 & Wilson et al. 1997 \\
RT30 & $183-211$ & 19 & 0.829 & 0.0130 & 0.862 & 0.0242 & 0.039 & Wilson et al. 1997 \\
\hline
\end{tabular}

${ }^{\dagger}$ Reverse primer

${ }^{\ddagger}$ Forward primer 
Table A2.2. Pairwise FST values based on microsatellites for the three major groups identified by structure analysis (below diagonal) and pairwise $P$ values (above diagonal).

\begin{tabular}{lccc}
\hline \hline FST & $\begin{array}{c}\text { Barren- } \\
\text { ground }\end{array}$ & $\begin{array}{c}\text { Boreal } \\
\text { woodland }\end{array}$ & Mountain \\
\hline Barren-ground & - & 0.0000 & 0.0000 \\
Boreal woodland & 0.040 & - & 0.0000 \\
Mountain & 0.011 & 0.041 & - \\
\hline
\end{tabular}

Table A2.3. Pairwise Rst values based on microsatellites for the three major groups identified by structure analysis (below diagonal) and pairwise $P$ values (above diagonal).

\begin{tabular}{lccc}
\hline \hline $\mathrm{R}_{\mathrm{ST}}$ & $\begin{array}{c}\text { Barren- } \\
\text { ground }\end{array}$ & $\begin{array}{c}\text { Boreal } \\
\text { woodland }\end{array}$ & Mountain \\
\hline Barren-ground & - & 0.0303 & 0.0028 \\
Boreal woodland & 0.030 & - & 0.0269 \\
Mountain & 0.003 & 0.027 & - \\
\hline
\end{tabular}

Table A2.4. Pairwise $\Phi_{\mathrm{ST}}$ values based on mtDNA for the three major groups identified by structure analysis (below diagonal) and pairwise $P$ values (above diagonal).

\begin{tabular}{lccc}
\hline \hline$\Phi_{\mathrm{ST}}$ & $\begin{array}{c}\text { Barren- } \\
\text { ground }\end{array}$ & $\begin{array}{c}\text { Boreal } \\
\text { woodland }\end{array}$ & Mountain \\
\hline Barren-ground & - & 0.0000 & 0.0000 \\
Boreal woodland & 0.079 & - & 0.0000 \\
Mountain & 0.138 & 0.173 & - \\
\hline
\end{tabular}


Table A2.5. Analysis of molecular variance (AMOVA) based on mtDNA haplotype data for the three groups identified by structure analysis. FST represents the variance within groups relative to the total variance.

\begin{tabular}{lccccc}
\hline \hline Source of variation & d.f. & $\begin{array}{c}\text { Variance } \\
\text { components }\end{array}$ & \% Variation & $\mathrm{F}$ & $\mathrm{P}$ \\
\hline Among groups & 2 & 0.63 & 13.9 & & \\
Within groups & 334 & 3.91 & 86.1 & $\mathrm{~F}_{\mathrm{ST}}=0.139$ & 0.0000 \\
\hline
\end{tabular}




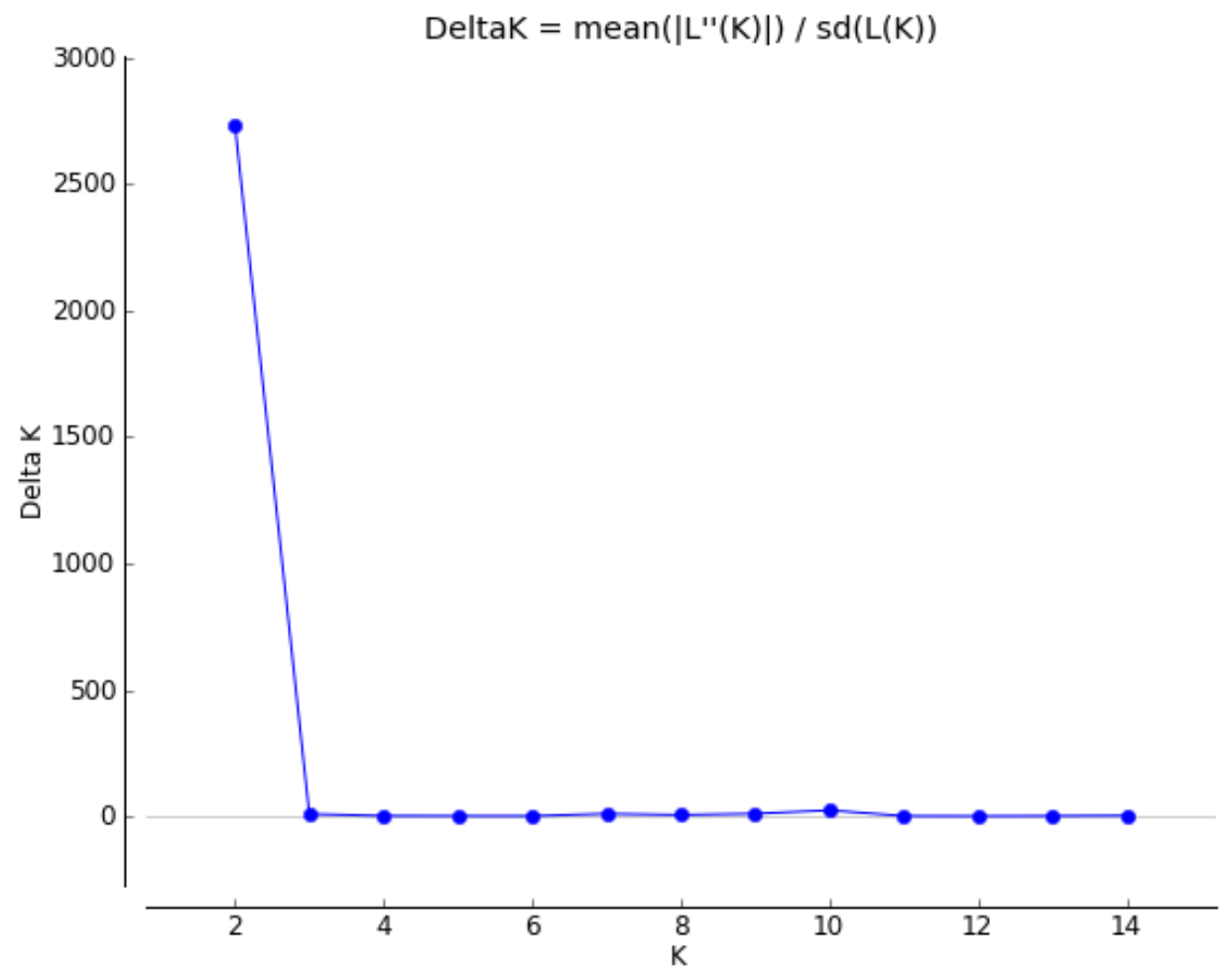

Figure A2.1. Most likely number of population clusters $(K=2)$ identified by the Evanno method (Evanno et al. 2005) using Structure Harvester v0.6.94 (Earl and vonHoldt 2012). 


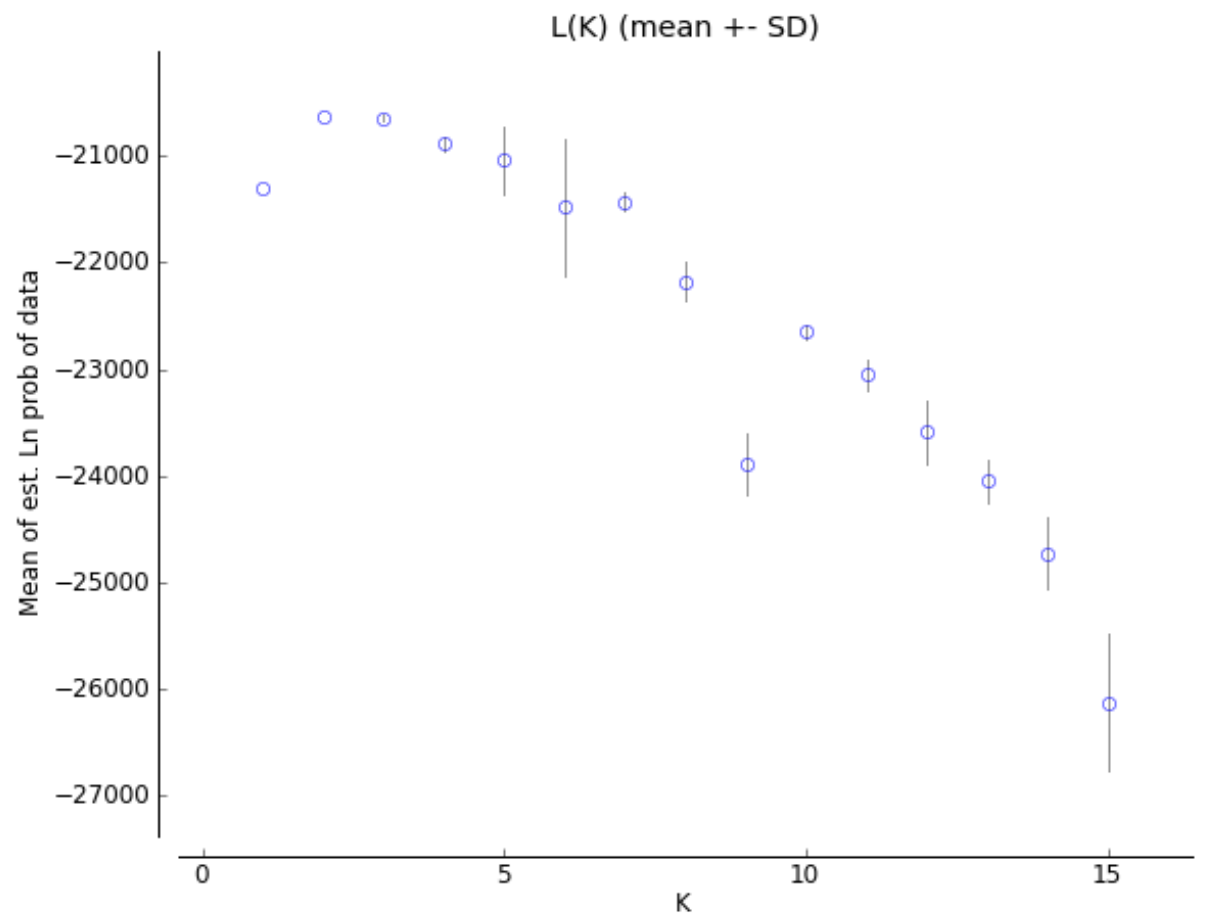

Figure A2.2. Mean likelihood for each K plus standard deviation as retrieved from Structure Harvester v0.6.94 (Earl and vonHoldt 2012). 


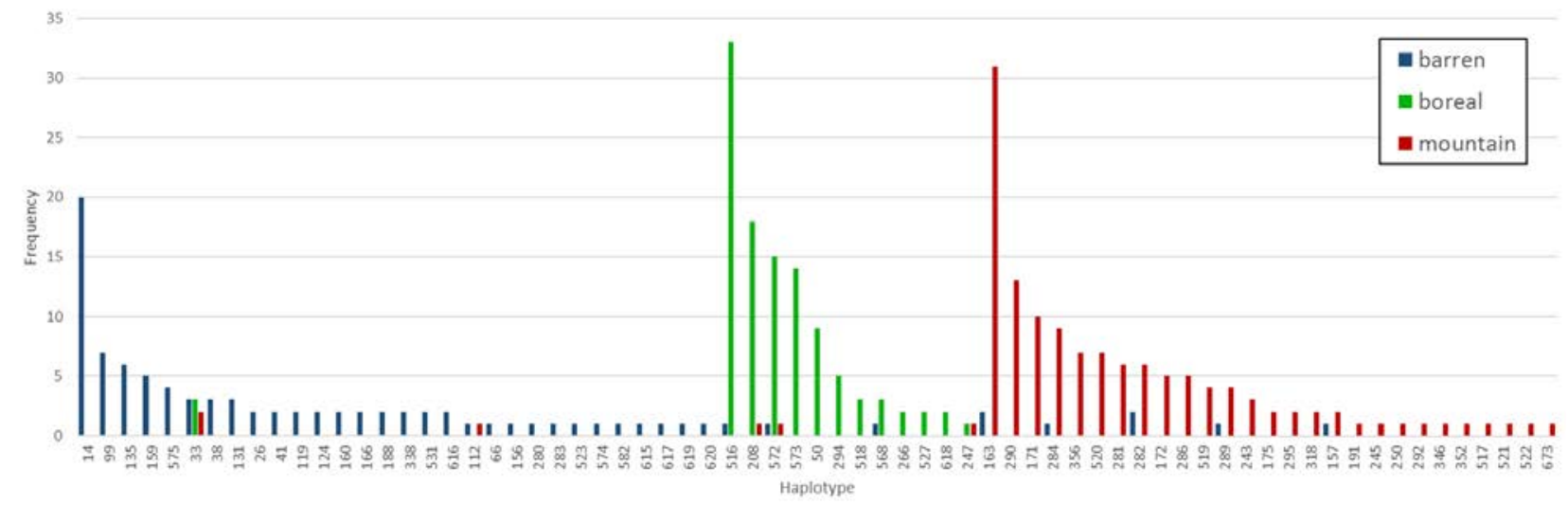

Figure A2.3. Frequency of mtDNA haplotypes for the three major groups identified by structure analysis: 1) barren-ground (blue), 2) boreal woodland (green), and 3) mountain (red). Three haplotypes belong to the North American haplogroup lineage (NAL): 50, 522 and 523, all other haplotypes belong to the Beringian-Eurasian haplogroup lineage (BEL). 


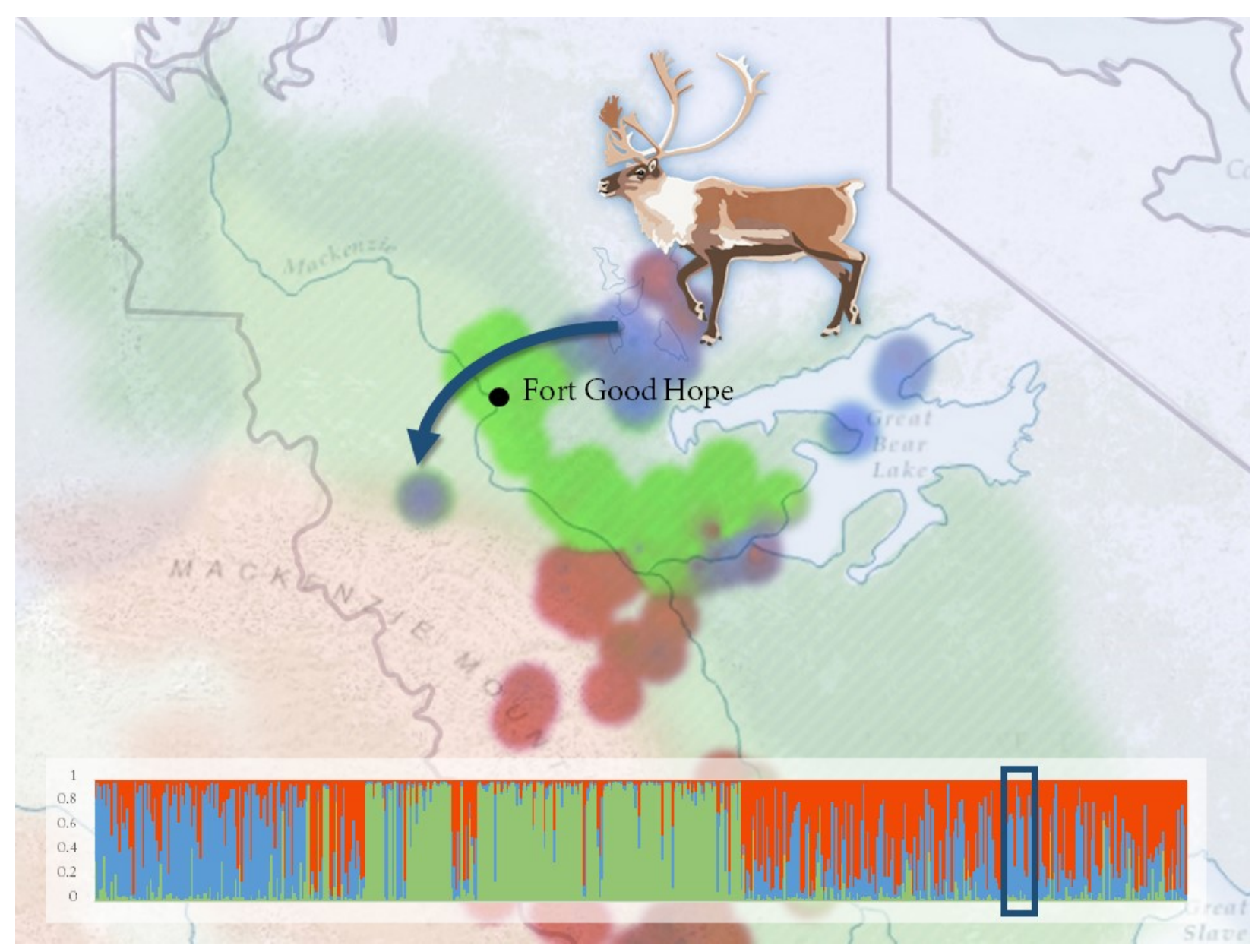

Figure A2.4. During a focus group meeting, Gabe Kochon of Fort Good Hope, Northwest Territories, Canada, described a historic event where a large herd of caribou crossed the Dehcho (Mackenzie River) and headed into the foothills of the mountains many years ago. We collected samples from the area identified by the arrow during our 2 April 2014 helicopter survey and identified 9 individual caribou from the site in subsequent genetic analysis. Structure analysis of these samples found a high probability of assignment (average 0.73) to the barren-ground caribou cluster (shown as blue in bottom bar and represented as blue on the map). Genetic structure analysis identified k=3 clusters of 1) barren-ground (blue) 2) boreal woodland (green) and 3) mountain (red). 


\section{LITERATURE CITED}

Bishop, M. D., S. M. Kappes, J. W. Keele, R. T. Stone, S. Sunden, G. A. Hawkins, S. S. Toldo, R. Fries, M. D. Grosz, and J. Yoo. 1994. A genetic linkage map for cattle. Genetics 136:619-639.

Earl, D. A., and B. M. vonHoldt. 2012. STRUCTURE HARVESTER: a website and program for visualizing STRUCTURE output and implementing the Evanno method. Conservation Genetics Resources 4:359-361.

Evanno, G., S. Regnaut, and J. Goudet. 2005. Detecting the number of clusters of individuals using the software STRUCTURE: a simulation study. Molecular Ecology 14:2611-2620.

McLoughlin, P. D., D. Paetkau, M. Duda, and S. Boutin. 2004. Genetic diversity and relatedness of boreal caribou populations in western Canada. Biological Conservation 118:593-598.

Moore, S., W. Barendse, K. Berger, S. Armitage, and D. Hetzel. 1992. Bovine and ovine DNA microsatellites from the EMBL and GENBANK databases. Animal Genetics 23:463-467.

Wilson, G., C. Strobeck, L. Wu, and J. Coffin. 1997. Characterization of microsatellite loci in caribou Rangifer tarandus, and their use in other artiodactyls. Molecular Ecology 6:697699. 